Ante AIKIO (Oulu)

\title{
On Germanic-Saami contacts and Saami prehistory ${ }^{\prime}$
}

\section{Introduction}

Systematic research on Scandinavian loanwords in Saami began well over a century ago (e.g. Thomsen 1869; Qvigstad 1893; Wiklund 1896). However, the concept of earlier Germanic borrowings in Saami is newer. In the 1960s it was still commonly maintained that few, if any, independent Indo-European loanwords had been directly adopted into Pre-Saami (e.g. Sköld 1961 passim). Of course, ever since the loanword studies by Thomsen $(1869,1890)$ it had been known that a few older Indo-European loan items, such as North Saami ruovdi 'iron' ( $<$ Germanic) and luossa 'salmon' ( $<$ Baltic), were present in Saami. But as such words were shared with Finnic whose lexicon showed a significantly stronger Indo-European impact, it was maintained that these words had been mediated to Saami by Finnic. Thus, there seemed to be little evidence of direct contacts between Pre-Saami and the early Germanic and Baltic tribes.

During recent decades it has become clear that this classical picture had been influenced by the ways in which etymological research was conducted. With the exception of studies of Scandinavian loanwords which have a long and fruitful research history, there has been a tradition of treating Saami etymology as a sort of extension of the etymological study of Finnish vocabulary; until recent times few researchers had taken the etymologisation of Saami words as an aim in itself. Recently this tradition has been changing, though. For instance, the thorough studies of Germanic loanwords conducted by Jorma Koivulehto have revealed that there is much more to the contact history of Saami and Germanic than was previously thought.

The purposes of this paper are to examine the strata of old Germanic borrowings in Saami and to discuss the prehistory and formation of the Saami language branch in the light of what is known of its contacts with Germanic as well as other language groups. The next section summarises the present knowledge of the stratification of Germanic borrowings in Saami. In the third section 27 Saami words are etymologised as early Germanic loans. The concluding section discusses the main lines of Saami ethnic history on the basis of the results of the present study as well as other recent linguistic research.

\section{The stratification of Germanic loanwords in Saami}

Jorma Koivulehto has demonstrated in his studies that there are two distinct strata of Germanic loanwords in Saami which precede the extensive stratum of 
Proto-Scandinavian loans, the existence of which has already for long been recognised. Even these older borrowings seem to have been adopted largely independent of Finnic, as most of them do not have Finnic cognates. Koivulehto's stratification of the Germanic loan items in Saami is summarised below, as it provides the background for the study in the next section; see e.g. Koivulehto (2002) and the references mentioned there for further material.

The oldest stratum of Germanic loanwords has participated in all the known Proto-Saami vowel changes, including the shift $* a>* u o .{ }^{2}$ These loanwords are often, but not always, shared with Finnic. In this layer of borrowings Saami $* k$ occurs in the place of Germanic * $h$. The words were borrowed either before the Germanic sound shift (i.e. before Indo-European $* k>$ PGerm $* h$ ) or at an intermediate phase when the Germanic sound was still pronounced as a velar fricative $\left({ }^{*} x\right)$. Examples of borrowings in this layer include:

- SaaN guos'si 'guest' < PS *kuossēe $<$ PreS *kansa ( Finn. kansa 'people, crowd') < PGerm *hansō- (> Old English hōs 'crowd, host', Old High German hansa id.) $)^{3}$ (LÄGLOS s.v. kansa)

- SaaN gierdat 'to endure' < PS *kiertë- < PreS *kärti- $\sim \sim$ Finn. kärsiä 'to suffer; to endure') $<$ PGerm *hardja- (> Swedish härda 'to harden, to endure') (LÄGLOS s.v. kärsiä)

- SaaSk kuârgg 'range of rocks, reef', SaaL guorgoj 'rocky shore' < PS $* k u o r k \bar{o}(j)<$ PreS *karko(j) < PGerm *hargu- (> Old Norse horgr 'heap of rocks; sacrificial site') (LÄGLOS s.v. karkea)

The second stratum of Germanic loanwords has also participated in many ProtoSaami vowel changes, such as $* a>* u o$, but shows $\varnothing$ as the substitute for Germanic $* h$. These loanwords are not shared with Finnic - there are no loanwords in Finnic showing a loss of foreign $h$. These borrowings were thus adopted at a stage when Saami and Finnic were already distinct languages spoken in two mutually exclusive speech communities, but these languages still closely resembled each other, as at least most of the complex Proto-Saami vowel shifts had not yet taken place. Examples of borrowings in this layer include:

- SaaN vuoma $\sim$ vuopman 'a kind of hunting fence' < PS *vuomën $<$ PreS *amin < PGerm *hamen- (> Old High German hamo 'hunting net; net in a weir') (Koivulehto 2002: 589)

- SaaN vuoksa 'depth of a fishing net' < PS *vuopsë < PreS *api/as < NwGerm *hāba-z (< PGerm *hēba-z) (> Old Norse háfr 'pocket net, hoop net') (Koivulehto 1999b: 364-365; 2002: 589)

- SaaN vuos'su 'bellows' < PS *vuosëjo < PreS *asijo < PGerm *hasja- (> Icelandic hes 'skin pouch') (Koivulehto 1999a: 365-367) 
In the case of individual words it is often impossible to distinguish between these two layers of borrowings. Indeed, there are quite a few Germanic borrowings which have undergone the Saami vowel shift $* a>u o$ and hence must have been adopted during one of these two early periods, but there are no criteria for more exact dating. But, even though the majority of the old Germanic loanwords in Saami are phonologically ambiguous so that their adoption cannot be with any certainty assigned to either the first or the second phase of borrowing, a principal distinction between these two strata must be assumed in order to explain the two reflexes of Germanic $* h$-. The following cases are ambiguous in respect to their stratification:

- $\quad$ SaaN buoidi 'fat' < PS * puojte < PreS *pajta < PGerm *faita- (> Old Norse feitr 'fat') (Koivulehto 1976: 260)

- SaaL buollda 'hillside, mountain side' ( Finn. dial. palsi 'hard layer of soil or clay, e.g. in the bottom of a lake') < PS *puoltë < PreS *palti < PGerm *falpa- (> Engl. fold) (Koivulehto 1976: 254-257)

- SaaL guobas 'witch' ( Finn. kave 'creature; mythological being; girl, maiden (myth.)') < PS *kuopës < PreS *kap-is < PGerm *skapa- (> Old English ge-sceap 'creature, creation'). (LÄGLOS s.v. kave)

- SaaN guolla 'testicle' < PS *kuolë < PreS *kali < PGerm *skallV- (> Old Engl. sceallan 'testicles', Old Frisian skall 'testicle'). PS *-l- in the place of foreign $*$-ll- is predictable in an early loan, as geminate sonorants were originally not permitted in Finno-Ugric. (The etymology derives from $J$. Koivulehto, p.c.)

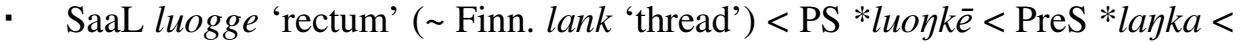
PGerm *langan- (> Icelandic langi 'rectum of a bovine') (LÄGLOS s.v. lanka)

- $\quad$ SaaN luoikat 'to lend' < PS *luojkkë- < PreS *lajkki- < PGerm *laigwē- I *laigweje- (> Old Norse leiga leigja 'to hire') (Koivulehto 2002: 588589)

- SaaN luoska (obsol.) 'decorative seam or trimming on the edge of a Saami man's coat' < PS *luoskë < PreS *laski < PGerm *laskV- (> Middle Low German lasch 'piece (of textile, leather, metal, etc.) with a sharp end; gusset in woman's coat'; cf. Norwegian lask 'invisible or decorative seam (on leather); cloth gusset', which is a Low German loan) (Koivulehto 1976: $262-263)^{4}$

- SaaN ruoksi 'udder' ( Finn. rauha-nen 'gland') < PS * ruovsē < PreS *rawsa $<$ *rawša $<$ PGerm *hrauza- (> Norwegian røyr 'groin') (cf. SSA s.v. rauhanen) 
- SaaN ruovda 'edge (of a boat, bed frame, shoe sole, etc.)' < PS *ruomtë < PreS * ramti < Pre-Germ *ramdō- (> PGerm *randō- > Old Norse rQnd 'edge') (Koivulehto 2002: 589)

- SaaN ruovdi ‘iron' ( Finn. rauta id.) $<$ PS *ruovtē $<$ PreS $*$ rawta $<$ PGerm *raudan- (> Old Norse rauði 'bog iron ore') (SSA s.v. rauta)

- SaaN suovdi 'gill; mouth, gullet' ( Finn. hauta 'pit; grave') < PS *suov $\delta \bar{e}$ $<$ PreS *saw $\delta a<*$ šaw $\delta a<$ PGerm *saupa- (> Old English sēap 'pit, hole; well, pool') (Koivulehto 1976: 35-37)

- SaaN suovri 'filthy person' < PS *suovrē < PreS *sawra < PGerm *saura( $>$ Old Norse saurr 'filth') (the etymology was presented by J. Koivulehto, p.c.)

- SaaN vuohčču 'narrow, wet bog' < PS * vuoččō < PreS *waććo < NwGerm *wātjō- (> Swedish dial. vät 'boggy place which gathers water in the spring and autumn') (Koivulehto 2002: 589)

- SaaN vuohppi 'small, narrow bay' ( Finn. apaja 'fishing ground') $<$ PS *vuopejē < PreS *apaja < PGerm *aban- (> Swedish dial. ave 'small and narrow bay of a lake') or *abjōn- (> Old Norse efja 'bay in a river; mire') (LÄGLOS s.v. apaja)

- SaaL vuolldo 'the strongest reindeer bull in the herd' $<$ PS *vuolto $<$ PreS *walto $<$ PGerm *waldan- (> Old Norse valdi 'ruler (poetic)') (Sammallahti 1984: 144; cf. Sköld 1961: 96)

- $\quad$ SaaN vuorbi ‘lot; destiny' ( Finn. arpa 'lot') $<$ PS *vuorpē $<$ PreS *arpa $<$ PGerm *arba- (> Old Norse arfr 'inheritance') (LÄGLOS s.v. arpa)

- SaaN vuordit 'to wait' (? Finn. vartoa, varrota id.) < PS *vuortē- < PreS *warta- < PGerm *wardō- (> Old Norse varða 'to guard, watch over') or *ward-ē- (> German warten 'to wait') (SSA s.v. varrota)

- SaaN vuordnut 'to swear' ( Finn. vanno- 'to swear') $<$ PS *vuornō- $<$ PreS *watno- < PGerm *wahwna- (> German er-wähnen 'to mention'); there are parallels for the substitution *-Kn- $>*_{-}-t n$ - (Koivulehto 1999b: 121)

- SaaN vuotta 'shoelace (laced around the thigh)' (? Finn. vanne 'hoop') < PS *vuont-ëk < PreS *want-ik < PGerm *wandu-z (> Old Norse vendr 'twig, whip') (Koivulehto 1976: 257-258)

- SaaN vuovdi 'forest' < PS *vuovte < PreS *awta < PGerm *aupa- (> Old Norse auðr 'uninhabited, desert', German öde id.; cf. Old Norse eyði-mork 'desolate forest land', German Ein-öde 'wilderness, wilds') (the etymology derives from P. Sammallahti, p.c.). As for the semantics, cf. SaaN meahcci 'wilderness, wilds, uninhabited territory' < Finn. metsä 'forest'. 
It must be noted that even the presence of a regular Finnic cognate does not guarantee that the borrowing belongs to the oldest stratum because it is possible that the words are quasi-cognates which show regular sound correspondence even though they do not go back to the common proto-language. It is likely that many words were borrowed between Pre-Finnic and Pre-Saami at a date when these languages were still phonologically relatively close to each other, just as e.g. many Scandinavian loanwords have recently diffused between the various Saami languages, conforming to regular correspondences as they were transferred between the already diverged idioms (see e.g. Sammallahti 1984: 145). Borrowings between relatively closely related languages frequently become conformed to the sound correspondences that are observed in cognate vocabulary, a process which can be called 'etymological nativisation' (see Aikio in press a).

Moreover, in some cases Finnic and Saami may have independently borrowed the same Germanic word. This is probably the case with SaaN vuordit 'to wait' and Finnish vartoa id.: Saami adopted the word from Proto-Germanic, whereas the Finnish item is likely to have been a later Proto-Scandinavian loan. Separate borrowing is supported by the irregular correspondence of the second syllable vowels (PS $* \bar{e} \sim$ Finn. $o$ ), as well as the narrow distribution of the Finnish word: vartoa is only attested in the western dialects of Finnish, and is absent in all other Finnic languages. ${ }^{5}$ Another likely case of separate borrowing is SaaN vuotta 'shoelace' $(<*$ want-ik) and Finn. vanne 'hoop' $(<*$ want-iš $)$, where the suffixal elements differ; in this case separate adoption has been argued also by Koivulehto (1976). It appears that even the oldest Germanic loanwords were adopted into Pre-Finnic and Pre-Saami largely independently of each other (see also Koivulehto 1988).

In contrast to the two strata discussed above, the later stratum of ProtoScandinavian loanwords is markedly different in phonological terms; and it is also lexically more extensive, containing several hundred borrowings. ProtoScandinavian borrowings can usually be easily distinguished from earlier loanwords on the basis of their vowel reflexes, because they were adopted after the series of sound changes that transformed the Pre-Saami vowel system into the Proto-Saami one - this process left none of the vowels in the system unaltered, and hence it could be called 'the great Saami vowel shift' (I owe the term to Janne Saarikivi). PScand $* a$ and $* \bar{a}$ are reflected as PS $* \bar{a}(>\mathrm{SaaN} a \dot{a})$ as opposed to the PS *uo $(<\operatorname{PreS} * a)$ in earlier loans. Likewise, PScand *e was rendered with PS *ie ( $>\mathrm{SaaN} i e$ ), whereas in older Germanic borrowings one finds PS $* \ddot{e}$ or $* e a$ (both $<$ PreS $* e$ under different conditions).

Consonant substitution patterns also differ from the earlier periods of borrowing. It appears that one must postulate an early dialectal division within Proto-Saami on the basis of how certain Proto-Scandinavian consonants were treated. In North-western Saami (henceforth NwS), which does not include the 
predecessors of Skolt and Kola Saami, the foreign consonants $/ \mathrm{h} /$ and $/ f /$ became established at quite an early date. ${ }^{6}$ Thus, in Proto-Scandinavian loanwords $* f$ - is reflected as $f$ - in NwS, but as $v$ - in Skolt and Kola Saami - but never as $p$ - in contrast to earlier borrowings. Foreign * $h$-, too, shows a dual treatment: in NwS it was inconsistently either dropped or retained, but in Skolt and Kola Saami always dropped. Medial * $h$ - was varyingly either replaced with $-k$ - or $-f$ - or assimilated to a preceding sonorant. Also some initial consonant clusters, especially $s k$-, were retained in Proto-Scandinavian loanwords in NwS, but simplified in the predecessor of the more eastern Saami idioms. A further consonantal criterion is that loanwords in the Proto-Scandinavian period frequently show the (hitherto unexplained) sound substitution PScand $*_{-j-}>$ Saami $*_{-} \check{c}_{-}$, which is not attested in earlier borrowings.

The following examples serve to illustrate the phonological characteristics of Proto-Scandinavian loanwords in comparison to the two earlier strata:

- SaaN áhpi 'high sea, open sea' < PS *āpe < PScand *haba- (> Old Norse haf'sea')

- SaaN ávža 'bird-cherry' < PS *āvče < PScand *hagja- (> Old Norse heggr 'bird-cherry')

- $\quad$ SaaN biergu 'meat' < PS *pierkō < PScand *bergō- (> Old Norse bjorg 'aid, rescue, food')

- SaaN fárru 'trip; party, travelling company' < NwS *fārō < PScand *farō( $>$ Old Norse $f o r$ 'journey, journeying'); cf. SaaSk väärr 'trip' < *vārō, with initial $v$-.

- SaaN fiel'lu 'board' < NwS *fiellō < PScand *felhō- (> Old Norse fjol 'board')

- SaaN háittis 'very hot (of stove)' $<\mathrm{NwS} *$ aajjttēs $<$ PScand *haita-z (> Old Norse heitr 'hot')

- SaaN lávkkis 'flea' < PS *lāvkkēs < PScand *flauha- (> Old Norse fló 'flea'); cf. SaaP laaffies 'flea' ( $<\mathrm{NwS}$ *läffês), with a different sound substitution!

- SaaN márfi 'sausage' < NwS *mārfē < PScand *marhwa- (> Old Norse $m o r r$ 'fat in the intestines')

- SaaN miel'li 'steep, sandy bank on the shore of a river or lake' < PS *mielle $<$ PScand *melha- (> Old Norse melr 'heap of sand')

- SaaN skálžu 'seashell' < NwS *skālčō < PScand *skaljō- (> Old Norse skel 'shell, crust'); cf. SaaK $k \bar{a} \bar{l} \breve{3}$ 'seashell' $(<* k \bar{a} l c ̌ c \bar{o})$, with simplification of the initial cluster. 
The adoption of Proto-Scandinavian loanwords was contemporaneous with the disintegration of Proto-Saami, as revealed by the dialectal differences in the patterns of phonological nativisation. This suggests that the loans were adopted into an already widely spread dialect continuum instead of a geographically narrow proto-language.

As this study concentrates on the earliest periods of borrowing, ProtoScandinavian loanwords will not be discussed below. The criteria set for the inclusion in the earlier strata of loans are phonological. A Germanic loanword must have already been adopted into Pre-Saami if it fulfils one of the following phonological criteria: 1) The word has participated in the vowel shift PreS $* a>$ PS *uo. 2) It shows the reflex of the metaphonic change PreS $* e(-i)>* i(-i)>$ PS $* \ddot{e}(-\ddot{e})$ or PreS $* e(-\ddot{a})>* \ddot{a}(-\ddot{a})>$ PS $* e a(-\bar{e})$. 3) It shows the sound substitution PGerm *f- $>$ PS * $p$ - or PGerm *h- $(* x-)>$ PS *k-

In addition to these criteria also the lowering and velarisation of PreS $* i$ to PS $* \ddot{e}$ is probably a valid criterion for early Germanic origin. This change is

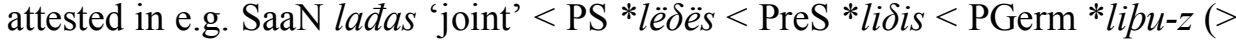
Old Norse liðr id.) and in an even earlier borrowing from the same word, SaaN lahttu 'limb' < PS *lëttō < PreS *litto (Koivulehto 2002). However, I have not discovered any new examples of Germanic loanwords displaying this vowel correspondence, so it is not of relevance to the present study.

\section{New Germanic loan etymologies}

In the etymological articles below the lexical material from Saami and Germanic is first presented, with references to the relevant etymological dictionaries. Only one or two members of each Saami cognate set are cited as examples. The intra-Saami distribution of each item is given in parentheses, together with a reference to Juhani Lehtiranta's common Saami vocabulary (YSS) if the cognate set can be found there. The following dictionaries, which have been used as sources of Saami lexical data, are not separately referred to: Bergsland \& Mattsson Magga 1993 (South Saami); Lagercrantz 1939 (South Saami, Pite Saami, Sea Saami); Schlachter 1958 (Ume Saami); Halász 1891 (Pite Saami); Grundström 1946-1954 (Lule Saami); Friis 1887, Nielsen 1979 and Sammallahti 1989 (North Saami); E. Itkonen 1986-1991 and Morottaja \& Sammallahti 1993 (Inari Saami); Sammallahti \& Mosnikoff 1988 (Skolt Saami); T. I. Itkonen 1958 (Skolt, Kildin and Ter Saami). The cited forms have been normalised according to the modern orthographic standards of the Saami languages, except for Kildin Saami. 
3.I.

SaaN bahta 'arse, behind' (S-T; YSS 872) $<$ PS *pëtë $<<$ (via labial dissimilation) *potë $<$ PreS *puti

$<$ PreGerm *putV- 'arse; vagina' > PGerm *fudV-> Old Norse $f u \delta-$ 'vagina' (only attested in compounds), Icelandic fuð 'vagina', Middle High German vut 'vagina; arse', English (dialectal) fud 'buttocks; vagina' (? < Nordic). Note also German Fotze 'vagina', which either shows expressive

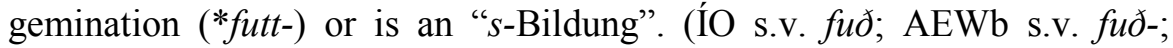
Kluge s.v. Fotze)

No etymology has been proposed for common Saami *pëtë 'arse, behind'. However, the word very closely resembles PGerm *fudV- (< PreGerm *putV-) 'arse; vagina'. The loan etymology is otherwise quite straightforward, but it requires the postulation of a sporadic labial dissimilation in $*_{o}>>* \ddot{e}$ after $* p$ in Proto-Saami. While the change is not regular, the Saami languages show a strong tendency towards this kind of dissimilatory development. Irregular variation between PS $* o$ and $* \ddot{e}$ next to labial consonants is relatively common. In North Saami one finds dialectal oscillation in many words, cf. e.g. monni manni 'egg', botnit batnit 'to plait', bohčit bahčit 'to squeeze; to milk' (SaaN $-a$ - reflects PS $*_{-} \ddot{e}$-). Illabialisation is also common in the other Saami languages; e.g. the three words above show only illabialised forms in Eastern Saami. The labial vowel is original in such cases, as demonstrated by extraSaami cognates (cf. Finn. muna 'egg', punoa 'to plait', pusertaa 'to squeeze, wring' < Proto-Uralic *muna, *puna-, *puśa-).

There are even other cases like PS * pëtë which uniformly show labial dissimilation in all Saami languages: cf. SaaN laksi 'dew' < PS *lëpse (the change $* p s>k s$ is regular in SaaN) < Proto-Uralic *lupsa 'dew' (> Komi lis-va 'dew', Tundra Nenets yøbta id., etc.) and SaaN avvit 'to leak (of boats)' $<$ PS *ëve- $<$ Proto-Uralic *uwa- 'current; to flow' (> Finnish vuo 'current', Mansi ow- 'to flow', etc.). Reflexes of the predictable regular forms *lopse and *ove- are not attested anywhere in Saami. A new example of this type can also be presented. One can connect SaaN bahkket 'to cram, stuff; to force oneself into', bahkat 'narrow, tight, taut' and bahku 'crowd', which are derivatives of a PS root *pëkë-, with Finn. pukea 'to dress, put on (clothes); to thread, slip into' (the previous comparison to SaaN bohkat 'to pierce' is hardly feasible, cf. SSA s.v. pukea).

Similar cases are also involved in SaaN savu: savvon- 'smooth waters (in a river)' (< PS *sëvōn) $\sim$ Finn. suvanto id. and SaaN lahppu 'lichen on trees' (< PS *lëppō) Finn. luppo id. On distributional grounds these words are probably not cognate, though, but more likely borrowings between Saami and Finnish. But even in this case one must postulate an original labial vowel *o in Saami, 
because otherwise one could not account for the $-u$ - in the Finnish forms: the sound substitution PS $* \ddot{e}>$ Finn. $u$ (or vice versa) is not attested in loanwords. As a further parallel, there is also another Germanic loanword which shows the same kind of labial dissimilation as the word *pëtë: cf. PS *këppë- 'to jump, run, gallop' <<PreS *kuppi- < PGerm *huppō(ja)- 'to jump, hop' (see 3.10.).

As there are numerous examples of sporadic labial dissimilation in Saami, it would not be too daring to assume that also SaaN bahta belongs to the group of words that have undergone this change. Moreover, there is in fact an obscured derivative in South Saami which has preserved a trace of the labial vowel: SaaS buhtehke 'the outermost part of the rectum of a reindeer' $(<\mathrm{PS}$ *potékkē). Thus, a Pre-Saami form *puti can be postulated, which in turn can be straightforwardly derived from Pre-Germanic *put $V$-. This borrowing is very likely older than the Germanic consonant shift, because borrowing from the Proto-Germanic form $* f u d V$ - (where $* / d l=$ phonetically $*[ð]$ ) would have resulted in PS *pëðë > SaaN *bađđa; cf. e.g. SaaN lieđđi 'flower' < PS *lie $\bar{e}<$ PGerm *blëda- (> Old English blōed 'flower, blossom; fruit'), which shows a spirant as the reflex of PGerm ${ }^{*}-d-=*[ð]$. But in fact many other Germanic borrowings may have been adopted before the consonant shift as well; in most cases there is just no phonological criterion that would allow this to be determined.

Semantically the loan etymology is perfect, as 'arse, behind' has been reconstructed as the original meaning of the Germanic item as well (Kluge s.v. Fotze). Notably, the secondary meaning 'vagina' is also attested in the South Saami cognate: SaaS bahte bïhte 'arse; vagina'.

3.2.

SaaS boelnedh 'to wilt (of grass, leaves; derogatorily of old people)' (S-L) $<$ PS * puolnë- < PreS *palni-

$<$ PGerm *falwnō- (> Old Norse fqlna 'to grow pale; to wilt', Icelandic fölna id.), a derivative of PGerm *falwa- (> Old Norse folr 'pale', Icelandic fölur id., German fahl id.). (ÍO s.v. fölur; VA s.v. falme; AEWb s.v. folr; SEO s.v. falna; Kluge s.v. fahl)

The Saami word *puolnë- 'to wilt', attested from South to Lule Saami, has not been etymologised. However, the word has a straightforward Germanic etymology. The PreS form of the word can be reconstructed as *palni-, which strikingly resembles PGerm * falwnō- 'to grow pale, to wilt'. The sound substitutions are quite regular. The PGerm cluster *-lwn- was predictably simplified by leaving the $* w$ without a substitute, as a three-consonant cluster would not have been possible in Uralic. Germanic ${ }^{*} \bar{o}$-stem verbs have been adapted as PreS $*^{*}$-stems in other cases, too; see etymologies 3.8., 3.10., 3.18., 3.22., and 3.26. 
Also the meanings of the Saami and Germanic words match very well; note that the Lule Saami cognate buollnat is glossed '(ver)welken, gelb, fahl werden (von Gras und Laub)' by Grundström (1946-1954: 756) and as 'vissna, gulna; falna (om glöd)' by O. Korhonen (1979a) (emphasis added).

Another Saami verb with an identical meaning can also be etymologised as a Germanic borrowing. SaaN goldnat 'to wilt (of grass, leaves etc.)' (< PS *kolnë-; attested in SaaL-I) derives from PGerm or PScand *gulnō- (> Norwegian gulne 'to turn yellow'). The word is a derivative of *gula- 'yellow' (> Norwegian $g u l$ ). Note that in this case, too, a PS * $\ddot{e}$-stem verb reflects a Germanic $* \bar{o}$-stem. This borrowing cannot be reliably dated; it could have been adopted either from Proto-Germanic or later from Proto-Scandinavian.

3.3.

SaaS boernes 'embryo' (not attested elsewhere in Saami) < PS *puornës < PreS *parnis

$<$ PGerm *barna- (> Old Norse, Icelandic, Norwegian and Swedish barn 'child') (ÍO, AEWb, SEO, VA s.v. barn)

The correspondence between SaaS boernes 'embryo' (< PS *puornës) and PGerm *barna- 'child' is rather self-evident, and the word can be analysed as a borrowing that has undergone the vowel shift $* a>$ PS *uo. The ending $-e s(<$ PS $*-\ddot{e} s)$ is probably a native suffix. The meanings of the words are not identical, but the etymology is still quite transparent. Furthermore, the Germanic item is originally a derivative of *ber- 'to bear, carry', and its original semantic motivation is thus 'one that is or was born in the womb'. This brings the comparison even closer to the South Saami word. The same Scandinavian word was also later borrowed into Saami a second time: cf. SaaN bárdni 'son', SaaS baernie 'unmarried son' (<PS * pārnēe).

\section{4 .}

SaaN boldni 'hillock, mound; roundish, steep hilltop', SaaS belnie 'hillock, mound; heap' $(\mathrm{S}-\mathrm{N})<\mathrm{PS} *$ polne $<$ PreS *pulna, cognate with Finnic *pullV- (> Finnish pullea 'plump, chubby', pullistua 'to distend, swell out, bulge out', pullottaa 'to bulge out, be bulging', olla pullollaan 'to be crammed, bulging, full of', etc.; Estonian (dial.) pullas 'chubby', pullakas 'large and fat')

$<$ PreGerm *fulna- > PGerm *fulla- 'full' (> Icelandic fullur, English and Norwegian full, German voll, etc.) (ÍO s.v. fullur; SEO, VA s.v. full; Kluge S.v. voll $)^{7}$ 
The equation of Saami boldni and Finnish pullea derives from P. Sammallahti (p.c.). In Saami one can assume the semantic development 'bulging object, something that bulges out' > 'hillock', 'heap'. The semantics of the Finnic cognates come particularly close to Germanic *fulna- 'full'; SSA even glosses Finn. pullea as 'rund, voll, dick' (emphasis added). It is also worth noting that the expression olla pullollaan 'to be crammed, bulging, full of' is practically synonymous with Finn. olla täynnään (< täysi 'full'). Phonologically the etymology is flawless. On account of Saami *-ln- the borrowing must have taken place before the assimilation *-ln- $>*_{-} l l$ - in Germanic.

According to SSA (s.v.), Finn. pullea is a "descriptive" word, but this hardly provides a viable alternative to the loan etymology presented here. First, 'descriptivity' (i.e. sound symbolism) as such does not yet explain the origin of a word, and second, in the case of pullea it is even hard to agree with the suggestion that the word is sound-symbolic (what are the putative symbolic conventions that this word displays?). SSA also mentions the similar SaaN words bullas, bul'lái 'thick, bulging', bul'lát 'to bulge out', bul'li 'swelling; reindeer with thick udders", and maintains that they might be "partially" of Finnish origin. What this means is unclear; all the cited items are obvious loans from Finnish.

3.5 .

SaaN (dial.) borsi 'foaming rapids in a canyon' (not attested in the other Saami languages) $<$ PS *porse $<$ PreS *pursa or *purša ( Finnish (dial.) purha 'waterfall', unless this is a parallel borrowing)

$<$ PGerm *fursa- 'rapids; waterfall' (> Old Norse fors $\sim$ foss, Swedish fors, Norwegian and Icelandic foss id.) (ÍO, VA s.v. foss; AEWb, SEO s.v. fors)

The word borsi is only marginally attested in the North Saami dialects (Qvigstad 1944: 14), and it is not included in the main dictionaries. However, it must earlier have been in more frequent use at least in North Saami, as it occurs in river names in various areas. ${ }^{8}$ The word is an obvious borrowing from PGerm *fursa- 'rapids, waterfall'. Due to the sound substitution $*_{-} f_{-}>*^{*}$ - the borrowing must have taken place quite early. A much newer borrowing from the same Germanic word is SaaS fuersie 'rapids' $(<*$ fuorsē); this must have been adopted either from Old Norse fors or from an even later Nordic language.

It is possible that SaaN borsi has a cognate in Finnish, cf. dialectal Finnish purha 'waterfall' ( $<$ PreF * purša). These words were compared (with a question mark) in SKES (s.v. purha), but this phonologically regular comparison has for some reason been left unmentioned in SSA (s.v.), even though the Saami verb boršut 'to foam (e.g. of rapids, waterfall)' is mentioned; the latter word is apparently a separate borrowing from the same Germanic word family, see 3.6. 
However, Finnish purha might also be a separate borrowing from Germanic. Regardless of which is the case, the Finnish item must also have been borrowed quite early, as it shows the development $* \check{s}>h$. The Finnic item was added to this etymology by J. Koivulehto (p.c.).

\section{6 .}

SaaN boršnt 'to foam (e.g. of rapids, waterfall), to bubble, seethe (of boiling water)' (S-K; YSS 959) < PS * poršo- < PreS *puršo- (with the secondary PreS $* \check{s}$, which emerged only after primary Proto-Uralic $* \check{s}$ had shifted to PreS * $s$ at an early stage; see Sammallahti 1998: 190)

< PGerm *fursja- (> Old Norse fyrsa 'to foam (of a waterfall)', Icelandic fyssa 'to foam (of stream, rapids, etc.'), a derivative of PGerm *fursa- 'waterfall, rapids' (ÍO s.v. fyssa; AEWb s.v. fyrsa); cf. 3.5.

The word boršut contains the secondary Proto-Saami sibilant $*^{\prime}$, which is distinct from both Proto-Uralic $* \check{s}(>\mathrm{PS} * s)$ and $*_{s}^{\prime}(>\mathrm{PS} * \check{c})$. As the secondary $*_{\breve{s}}$ does not occur in shared Uralic vocabulary, the word boršut must be an innovation adopted during the separate development of Saami. Due to the marked cluster -rš- the word has a somewhat sound-symbolic ("descriptive") colour, but this does not hinder the loan etymology.

Indeed, PS *poršo- can be straightforwardly analysed as a borrowing. A suitable original is provided by the Germanic verb *fursja-, a derivative of *fursa- 'rapids, waterfall'. The latter is reflected in another loanword, SaaN borsi 'foaming rapids in a canyon' (see 3.5.). The loan etymology is semantically flawless, as identical meanings are attested in Saami and Scandinavian. The assumed sound substitution $*_{-s j-}>*_{s}$ is natural: the secondary Proto-Saami $\check{s}$ was inherently palatalised $(=*[\check{s}])$, and hence it is a predictable substitute for a foreign sequence $-s j$-. As a parallel one can cite SaaN áššu 'glowing coals' $<$ PS *āšo $<$ PScand *asjō- (> Swedish ässja 'hearth in a smithy').

The South Saami cognates show irregular oscillation between PS $*_{s}$ and $*_{s}$ : SaaS bårsedh $\sim$ barsjedh $\sim$ borsedh 'to stream; to roar, rush (of water in a large river)'. This is probably due to the expressive character of the word. However, the irregular $-s$ - might also have developed due to the influence of the separate borrowing *porse 'rapids in a canyon', which has not been preserved in South Saami. 
3.7 .

SaaN deahkki 'thick meat, muscle' (U, L-T; YSS 1240) < PS *teakkē < PreS *tekkä

< PGerm *bekwia- 'thick' (> Old Norse pykkr, German dick, English thick, etc.) (ÍO s.v. pykkur; VA s.v. tykk; SEO s.v tjock; Kluge s.v. dick)

In etymological references SaaN deahkki has been considered cognate with Finn. $t \ddot{a} k k \ddot{a}$ 'thick meat on the chest of a game bird' (e.g. SSA s.v.). However, this word is systematically attested only in northern Finland, in addition to which there are scattered attestations in parts of northern Savo, North Karelia, and central and northern Ostrobothnia (LAFD). On distributional grounds the Finnish item is thus obviously a Saami substrate loanword; the sound substitution $e a>\ddot{a}$ is regular in borrowings from Saami.

SaaN deahkki regularly reflects PreS *tekkä, which can be compared to the Germanic adjective *pekwia- 'thick'. Phonologically the etymology is unproblematic; the sound subsitution $*_{-} k w->*_{-} k k$ - is natural, as a cluster $*_{-} k w$ - was not permitted by Uralic phonotaxis. As for the semantics, the Saami items are widely glossed as 'thick meat' in dictionaries: SaaN deahkki 'meat without bone, the thick meat' (Nielsen 1979 s.v. doek'ke), 'Muskel, dickes Fleisch beim Menschen und Tieren' (Lagercrantz 1939 no. 7791), SaaI tekki 'das dicke, knochenlose Fleisch' (E. Itkonen 1986-1991 s.v.), SaaSk teä'kk 'knochenloses dickes fleisch' (T. I. Itkonen 1958: 579) (emphasis added). There also exists a good parallel for the semantic development: Finn. tykky 'thick, stout; snow load on trees; lean meat, meat with little fat', which is a later borrowing from the same Germanic word family, cf. Old Norse bykkr 'thick' (Koivulehto 1996).

3.8.

SaaS doerpedh 'to need', SaaP (der.) <tuorptet $>$ (=tuor'patit or tuorpatit) 'to need, require, be necessary' < PS *tuorp $\ddot{e}$ - $<$ PreS *tarpi-

$<$ PGerm *parbō- (> Old Norse parfa 'to be necessary') (ÍO, AEWb s.v. parfa)

The PS root *tuorpë- is only attested in SaaS doerpedh and in a suffixed form in old Pite Saami <tuorptet>; the latter word is only found in Halász's dictionary (1891), and the notation must represent either SaaP tuor'patit (<*tuorpë-té-) or tuorpatit (<*tuorpë-tte--). The etymological connection between SaaS doerpedh 'to need' and the Germanic item was already noticed by Lagercrantz (1939 no. 8092 b), who however mistakenly interpreted the word as a Scandinavian borrowing. This is not possible due to the sound correspondence PS *uo $\sim$ PScand $* a$. There is also an ablaut form with $-u$ - in Germanic (cf. Old Norse purfa 'to 
be required, needed', Old High German durfan, Old English Jurfan, etc.), but Saami *-uo- cannot reflect foreign - $u$ - either. But Lagercrantz's etymology can be rehabilitated in a slightly different form. The sound correspondence receives its explanation if we assume that the word was already borrowed into Pre-Saami in the form *tarpi-, which then underwent the regular change $* a>* u o$. The nativisation of a Germanic $* \bar{o}$-stem verb into the Pre-Saami class of $* i$-stems has occurred in many other cases, too (cf. 3.2., 3.10., 3.18., 3.22. and 3.26.).

The same Germanic word has also been adopted into Finnic, cf. Finnish tarve (tarpee-) 'need' and tarvita (tarvitse-) 'to need'. Due to their different suffixes these items are most probably separate borrowings and not cognate with SaaS doerpedh. There is also a separate, later borrowing in Saami from the same Germanic word family: SaaN dárbu 'need' < PScand *barbō $(>$ Old Norse porf 'need, necessity'). Also Finnish tarvita 'to need' has been further mediated to Saami, cf. SaaN dárbbašit 'to need'. This loan item shows an extensive distribution, reaching from South Saami to Skolt Saami. It is possible that this later Finnic borrowing has largely replaced the reflexes of the older loanword *tuorpë-.

3.9.

SaaN duoddut 'to bear, stand, tolerate', SaaS duedtedh 'to endure hard weather (of draught reindeer)' (S, N-K) < PS *tuont-ō-, *tuontē- < PreS *tanta-

$<$ PGerm *standa- 'to stand' (> English stand, Gothic standan, Old Norse standa etc.) (ÍO s.v. standa; VA, SEO s.v. stå)

The Saami word family has not been included in Lehtiranta's common Saami vocabulary (YSS) in spite of its wide distribution. The forms in North Saami and eastern Saami reflect a labial stem (PS *tuontō-). The labial vowel can be analysed as a suffix. The original illabial stem *tuontēe- is preserved in a specialised meaning in SaaS duedtedh 'to endure hard weather (of draught reindeer)'; all the other Saami languages show a more general meaning 'to bear, stand, tolerate'. The Pre-Saami form of the verb can be reconstructed as *tanta-, which can be analysed as a borrowing from Proto-Germanic *standa- 'to stand'.

The semantics of the Saami word exactly matches the secondary meaning 'to stand' = 'to bear, endure, tolerate', which in addition to English is attested in at least Old Norse (IED: 588). A parallel semantic relation also occurs in Finn. sietä̈ 'to bear, stand, tolerate' ( $<\mathrm{PF} *$ sêtä-). This word consists of the stem $*_{s} \bar{e}$ - and the verbal suffix *-tä-, and the stem is very probably a borrowing from PGerm *stē- 'to stand' (> Swedish stå, Old High German stän, etc.) (cf. SSA s.v.). Moreover, the meaning Knud Leem has attested for SaaN duoddut brings the comparison even closer: duodom [= duottun] 'staaer fast, bestandig, saa jeg 
ei faldes, saasom havende beqvemt Rum at staa paa' (= 'I stand firm, secure, so that I do not fall, as I have a comfortable room to stand in'; here cited according to Nielsen 1979 V: 22).

Phonologically the etymology is quite self-evident. It is true that in the early Germanic loanwords of Finnic the initial cluster *st- was usually rendered

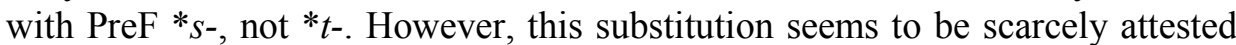
in the independent loanwords in Saami. There is one clear example, SaaN soabbi 'staff, stick' $<$ PS *soampe $<$ PreS *sompa $<$ Indo-European *stomb ${ }^{h} o->$ Old Indic stambha- 'post, column, pillar' (Sammallahti 1999: 81), but as this loanword seems to be quite old, it does not rule out the idea that the substitution $*_{s t-}>*_{t}$ - was possible in a later Germanic borrowing.

3.10.

SaaL gahppat 'to jump, leap', SaaU gah'pat 'to gallop', SaaS gahpedh 'to climb; to jump and run around; to rise on the hind legs and kick with the forelegs (of reindeer)' < PS *këppë- << (via labial dissimilation) *koppë-< PreS *kuppi-

$<$ PGerm *huppō(ja)- 'to leap, jump, hop' (> Old Norce, Icelandic, Swedish hoppa, English hop) or *huppia- id. (> Germ hüpfen) (ÍO, AEWb, SEO s.v. hoppa; Kluge s.v. hüpfen)

The verb *këppë- shows reflexes from South to Lule Saami, and the meanings oscillate between 'jumping', 'running', 'galloping', and the like. The word shows a notable resemblance to Germanic *huppō(ja)- 'to jump, leap, hop'. The loan etymology is phonologically quite straightforward, as long as PS *këppëis analysed as a word that has undergone the sporadic labial dissimilation $*_{o}>$ $* \ddot{e}$ adjacent to labial consonants. There are numerous examples of this development; see 3.1. for parallels and discussion.

The substitution of PS *k- for PGerm * $h$ - $\left({ }^{*} x\right.$-) shows that the borrowing is quite old. This sound correspondence poses no problem to the etymology, as the same substitution is also attested in other borrowings which occur exclusively in Saami (see e.g. 3.11., 3.13.). As for the second syllable vowel, there are also many other examples of the substituion of PreS $*_{-} i$ - for Germanic $*_{-} \bar{o}$ - in verb stems (see 3.2., 3.8., 3.18., 3.22., 3.26.). 
3.II.

SaaN gavja 'dust', SaaSk kõbjj 'dandruff', SaaK kę̧jj 'dust' $(\mathrm{N}-\mathrm{T})<\mathrm{PS}$ *këpjë < PreS *kepji

$<$ PGerm *heuja- (> Old Norse hý 'down; colour (of the face)', Faroese $h y$ ggj 'thin layer of mould', Icelandic $h y$ ' 'down; fine hair (on the head or in the beard); small husks; dust', Swedish hy 'skin, complexion; appearance, colour (of face etc.)', Gothic hiwi 'appearance, form', English hue) (ÍO, AEWb s.v. $h y ́$; SEO s.v. $h y$ )

The North Saami word gavja 'dust' goes back to PS *këpjë, as demonstrated by the Skolt and Kola Saami cognates which have preserved the reflexes of PS * $p j$ distinct from those of $* j$. As the cluster $* p j-$ or indeed, any cluster consisting of a stop followed by a sonorant - does not conform to Uralic phonotaxis, the sound structure suggests that the word is of foreign origin.

Assuming that PS *këpjë reflects PreS *kepji (in theory also *kipji and *küpji would be possible), it can be quite plausibly compared to PGerm *heuja-. Most of the reflexes of this word show semantics along the lines of 'skin' 'appearance' 'colour', but in Scandinavian one also encounters meanings pertaining to various kinds of fine, flaky or fluffy substances such as 'down', 'fine hair', 'a thin layer of mould'. Even precisely the same meaning 'dust' is attested in Icelandic. The etymology is thus semantically flawless.

The vowel correspondence as well as the substitution of PreS $* k$ - for PGerm *h- $\left({ }^{*} x-\right)$ point to quite early borrowing. The etymology presupposes

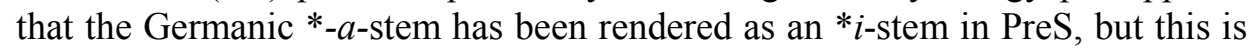
attested in several other borrowings as well: cf. e.g. SaaL buollda 'hillside, mountain side' ( $\sim$ Finn. dial. palsi 'hard layer of soil or clay, e.g. in the bottom of a lake') < PreS *palti < PGerm *falpa- (> Engl. fold) and SaaN dohppa 'sheath' < PreS *tuppi ( Finn. tuppi id.) < PGerm *duppa- > Middle Low German dop $\sim$ doppe 'sheath, case' (Koivulehto 1981: 141). ${ }^{9}$

The substitution of PS *-pj- for Germanic *-uj- remains slightly puzzling, though, as the cluster ${ }^{*}-v j$ - was also quite normal in Proto-Saami. However, it seems that this cluster originally arose in Proto-Saami through the sound change ${ }^{*} k j>* v j$, cf. e.g. SaaN ruovji 'quarter of a carcass' $\sim$ Finn. raaja 'limb' < * rakja. This sound change cannot be reliably dated, but it may well have taken place during a relatively late phase of Proto-Saami. If so, the cluster *vj could still have been phonotactically illegal in the period when the word *heuja- was borrowed, which would motivate the substitution $*_{-} u j->*_{-}-p j$-. It is worth noting that Finnic *-pj- has been substituted for Germanic $-u j$ - in some borrowings, presumably for the same reason: the sequence -Vuj- was illegal in Proto-Finnic. An example worth noting is Finn. hipiä '(human) skin' $<\mathrm{PF} *$ hipjä, which is a 
borrowing from a later form of the same Germanic word $(<*$ hiuja $<$ PGerm *heuja-) (SSA s.v.).

Another possible explanation (suggested by P. Sammallahti, p.c.) is that the final component of the Germanic diphthong was still pronounced as a bilabial glide at the time of borrowing (*hewja-), and Saami * $p$ was substituted for it because Saami $* v$ was phonetically a labiodental fricative. The phoneme $/ v /$ is pronounced as a labiodental even in preconsonantal position in e.g. South Saami, cf. e.g. SaaS jaevrie [jảv ${ }^{\ni}$ rie] 'lake'. The South Saami pronunciation is probably original compared to the bilabial glide in e.g. North Saami (cf. SaaN jávri [jàßri] 'lake').

Regardless of what the exact background of *pj in *këpjë 'dust' is, the etymology can hardly be doubted on this account, because an identical substitution is attested in a later borrowing from the same Germanic word: SaaS ibje 'dust' (< PS *ipjë) must derive from a later Scandinavian form *hiuja(*hiwja-?), reflecting the vowel development $*_{e u}>*_{i u}$. The lack of the shift $* i$ $>* \ddot{e}$ in Saami shows that this loanword was adopted after the lowering of PreS high vowels, and also the substitution $* h->\varnothing$ points to a later date of borrowing.

It seems that the same Germanic word *heuja- has been borrowed into Saami even more than twice. From this word one can derive also PS *jievjë 'white (of an animal, esp. a reindeer, rarely also of hair); white reindeer' $>$ SaaN jievja (S-P, N-K; YSS 273), which has not been previously etymologised. Semantically the connection is fairly transparent: in Saami the underlying meaning is 'beautiful in colour and appearance', as a completely white reindeer is considered especially beautiful by the Saami. The meanings 'colour', 'appearance' etc. are widely attested on the Germanic side.

Phonologically the loan etymology of PS *jievjë is quite clear, even though in this case ${ }^{*}-p j$ - was for some reason not applied as a substitute. The substiution $* e>$ PS $* i e$ is regular in PScand loanwords, as is $* h->\varnothing$-. The initial $*_{j}$ in the Saami form is not a substitute for $h$-, but instead a prothetic consonant necessitated by Saami phonotaxis: initial *ie- was not permitted in Proto-Saami. A prothetic $* j$ - has regularly developed before earlier initial $* i e$ - in inherited vocabulary, cf. e.g. SaaN jietna 'sound, voice' < PS *jienë < Proto-Uralic *äni ( Hungarian ének 'song').

In South Saami the reflexes of PS *jievjë show irregular vocalism: joevje jovje jyövje. The labial vowel could be attributed to the labialising influence of the following $-v-$, but analogy has also likely played a role here. The diphthong -oe- (< PS *-uo-) may be due to the influence of several other lexical items that describe the colour of reindeer and also end in -oevje: cf. SaaS boevje 'greyish brown reindeer', moevje- in moevje-miesie 'reindeer calf with a whitish brown colour' (miesie 'calf'), and *tjoevje. The last word was lost in South 
Saami, but it would be the predictable reflex of PS *cuovjë 'grey (of reindeer); blue', which is attested in all other Saami languages (YSS 215).

The same Germanic word *heuja- has even been borrowed into Saami for a fourth time: SaaN uvja 'down' was adopted from Old Norse $h y$ ' down'. This Scandinavian loan etymology is well-established (Qvigstad 1893: 338).

3.12.

SaaN geardni 'thin, frozen snow-crust; a scab-like disease in the udder of a reindeer cow' (L-T; YSS 389) < PS *kearnē < PreS *kernä

$<$ PGerm *herna- (> Old Norse and Icelandic hjarn 'hard frozen snow, snow-crust') (ÍO, AEWb s.v. hjarn)

In etymological dictionaries Saami geardni is considered cognate with Finn. kärnä 'hard tree-bark, rind; scab, rash; dried dirt, carbon deposit', Mordvin kšnat 'measles; itch' and Northern Khanty kărńi 'ice crust' (SSA s.v. kärnä; UEW: 138). The inclusion of the Khanty word in this set is unconvincing, though, as both the first syllable vowel and the palatalised nasal $-\dot{n}$ - are irregular; moreover, according to DEWOS (662) the word is connected with Northern Khanty kirńamt- 'to freeze slightly (of snow)', which in turn is a derivative of kir 'snow-crust' (< PU *keri 'skin, bark, crust'; UEW: 148-149). UEW maintains that the $-\dot{n}$ - in Mordvin and Khanty could have developed due to the influence of the palatal consonant environment, but this suggestion is puzzling because the word contains no other palatal(ised) consonants. In Mordvin the change $*_{n}>\dot{n}$ could be attributed to regular palatalisation before original front vowels, but no such sound change has taken place in Khanty.

Also the Finnic and Mordvin items might be unrelated to Saami geardni. The semantics of Finn. kärnä suggests that it may be an expressivised front vocalic variant of karna kaarna 'pine bark, rind; inner bark of birch; soot, dried dirt', Karelian koarna 'pine bark; scab, rash'. At least the words ka(a)rna and kärnä seem to have become associated and semantically influenced each other. The word $k a(a) r n a$ is probably in itself a contamination of two originally distinct borrowings: cf. Proto-Baltic *karnā- (> Lithuanian karnà 'bast; willow bark') and PGerm *skarna- (> Old Norse skarn 'muck, dirt') (cf. SSA s.v. kaarna).

Neither Finnic nor Mordvin shows the meaning 'snow-crust' which unites the Saami and Germanic items. On the other hand, the secondary meaning 'scab-like disease' in Saami connects the words naturally to the Finnic and Mordvin items; but this meaning is only attested in North and Lule Saami and thus it might be due to the later influence of Finnish. But even if, after all, all three words are related and derive from Saami-Finnic-Mordvin *kernä 
*kärnä, this does not provide a counterargument to the loan etymology, because other Germanic loanwords with a similar extensive distribution are also known.

The Germanic loan etymology of Saami geardni is straightforward: the meanings of the words are practically identical, and the sound correspondence is quite regular. The substitution of PreS $* k$ - for PGerm *h- $(* x-)$ shows that the borrowing is quite old. The Germanic word derives from Proto-Indo-European *kerno- and it is cognate with Russian серён 'strong crust of ice' and Armenian sarn 'ice'. The PGerm form has been reconstructed as *herzna- instead of *herna- in AEWb (s.v. hjarn), but there seems to be no necessity for postulating a medial *-z-. But even if this reconstruction is correct, it does not pose a problem for the loan etymology: the foreign three-consonant cluster would have had to be simplified in Saami.

\subsection{3.}

SaaS guejhtie 'strong heat (of open fire)', guejhtedh 'to warm strongly (of fire)' (not attested elsewhere in Saami) < PS *kuojttē(-) < PreS *kajtta(-)

$<$ PGerm *haita- 'hot' (> Old Norse heitr, German heiß, English hot, etc.) (ÍO s.v. heitur; AEWb s.v. heitr; SEO s.v. het; Kluge s.v. heiß)

SaaS guejhtie- is a nomenverbum root used both in the meaning 'strong heat' and 'to warm strongly (of fire)'. The word has no cognates in the other Saami languages, but it would regularly go back to PreS *kajtta-. This form is quite obviously a borrowing from PGerm *haita- 'hot'. The sound correspondence is quite straightforward. PreS $* k$ - has been substituted for Germanic *h- $(* x-)$ in the oldest stratum of borrowings; see also 3.10., 3.11. and 3.12. The substitution of a geminate for a foreign medial unvoiced stop is a well-known phenomenon in Germanic loanwords.

\subsection{4.}

SaaS guelhtie 'cold weather in summer', SaaU güelldee id. < PS *kuolte < PreS *kalta

< PGerm *kalda- 'cold' (> Old Norse kaldr, German kalt, English cold, Gothic kalds) (ÍO s.v. kaldur; VA s.v. kald; SEO s.v. kall; Kluge s.v. kalt)

The word *kuolte 'cold weather in summer' is only attested in South and Ume Saami. The sound correspondence between SaaS guelhtie and SaaU güelldee is not entirely regular: the former would reflect a geminated form *kuoltte whereas the latter reflects PS *kuoltē. However, in all likelihood the geminate in South Saami is secondary. A similar irregular gemination is found in a couple 
of other words as well: cf. e.g. SaaS vuelhtie 'from under' SaaU vüelldee id. < PS *vuol-tè, a separative of the spatial noun root *vuolē- 'space under / below'.

As PS *kuolte regularly reflects PreS *kalta, it is an obvious borrowing from PGerm *kalda- 'cold'. The loan etymology is phonologically regular, save for the secondary -lht- in South Saami. Also the semantic connection is obvious. The difference of word-class poses no problem; see 3.13. for an analogous case. Moreover, the word-stem also shows adjectival use in South Saami: cf. guelhties 'very cold (e.g. of summer, year, wind, etc.)'. From a synchronic point of view the final $-s$ is an adjective suffix, but diachronically the adjective might reflect the primary borrowing: the PGerm adjective *kalda-z could have been adopted into PreS in the form *kaltas, with ${ }_{-s}$ substituting the Germanic nominative singular suffix. Subsequently $-s$ could have been reanalysed as an adjective suffix, yielding the noun *kalta via retrograde derivation.

A phonologically and semantically close word is PS *kuoltō 'strong wind in winter, which blows snow up from the ground' $(<$ PreS *kalto). This appears to be a separate borrowing from the same Germanic word family (see 3.15.). It is also possible that PS *kuolte 'cold weather in summer' and PS *kuoltō 'strong wind in winter' were originally in a derivational relationship within Saami, but more likely they were separately borrowed from Germanic.

\subsection{5 .}

SaaN guoldu 'strong wind in the winter which blows snow up from the ground' (S-T; YSS 516) < PS *kuoltō $<$ PreS *kalto

$<$ some formation based on PGerm *kalda- 'cold' (> Icelandic kaldur, German kalt, English cold, Gothic kalds); note especially Icelandic kaldi 'breeze, cold and relatively strong wind' ( $<*$ kaldan-) and kalda 'to blow coldly, become cold' (<*kaldō-) (ÍO s.v. kaldur; VA s.v. kald; SEO s.v. kall; Kluge s.v. kalt)

Reflexes of the word *kuolto are attested in all Saami languages. In Skolt and Kola Saami the word means '(heavy) snowfall', but in the rest of the Saami languages its semantics is rather connected with wind. SaaN guoldu denotes the condition in which a strong wind blows snow up from the ground and causes it to drift, weather that is bitterly cold on open tundra. The Inari Saami cognate kuáldu has even been translated as 'frosty wind' ("pakkasviima"; Morottaja \& Sammallahti 1993 s.v.), with no reference to the drifting of snow. The word root is a nomenverbum; verbal cognates are found in all Saami languages except for North and Inari Saami: cf. SaaS gåaldodh 'to whirl (of drifting snow)', SaaL guolldot 'to cover the tracks or the way (of drifting snow)', SaaSk kuâlddad 'to snow'. 
No etymology has been proposed for the Saami word family. However, as the words regularly go back to PreS *kalto, they can be compared to PGerm *kalda- 'cold'. The semantic correspondence is quite transparent, and almost the same meaning is also attested in Icelandic kaldi 'breeze, cold and relatively strong wind' $(<*$ kaldan-). On the other hand, if the verbal usage of the Saami stem is primary, the word might have been adopted from PGerm *kaldō- ( $>$ Icelandic kalda 'to blow coldly'). Even though the exact loan original cannot be identified with certainty, the etymology is semantically quite transparent and phonologically regular. The second syllable labial vowel in Saami might originally have been an obscured derivational suffix, but it is also possible that $*_{o}$ was directly substituted for Germanic * $a$.

The Germanic origin of PS *kuolto is also supported by the fact that the members of the same Germanic word family seem to have been repeatedly borrowed into Finnic and Saami. A probably separate borrowing from PGerm *kalda- 'cold' is SaaS guelhtie 'cold weather in summer' (see 3.14.). Germanic *kalda- is originally a participle of *kala- 'to freeze, become cold' (Kluge s.v. kalt), and this underived form is also reflected in borrowings. A relatively recent loanword is SaaN gállu 'cold weather', which apparently contains the nominal suffix $-u\left(<\mathrm{PS} *_{-} \overline{)}\right)$ and a root borrowed from Old Norse kala 'to freeze' or its Proto-Scandinavian predecessor. The same Scandinavian word has also been borrowed into Finnic in a suffixed form, cf. Finn. kalea 'cool; hard', Karelian kalie 'cold weather in the autumn' (-ea, -ie is an adjective suffix).

A much older borrowing from the same Germanic word might be SaaN goallut 'to feel cold, to freeze' < PreS *kolo- ( Finn. kolea 'cool, chilly'; -ea is an adjective suffix). ${ }^{10}$ The vocalism could be explained by assuming that the word had already been adopted from PreGerm *kolo-, which later developed into PGerm *kala- via the change $*_{o}>*^{*} a$. This would implicate a very early date of borrowing. However, Finn. kolea and SaaN goallut might also derive from PGerm *kōlja- 'cool' (> German kühl, etc.) (Nikkilä 1981: 74; LÄGLOS s.v.). On the other hand, the form *kōlja- seems to have been borrowed from Proto-Scandinavian into Lule Saami as kuolltje 'cold north wind' $<* k u o l c ̌ e ́ e$ (note, though, that in Scandinavian *kōlja- has been attested in verbal use only; VA s.v. kjøle). The substitution of Saami $-\check{c}$ - for PScand $*_{-j}$ - is widely attested (see section 2). The semantics of SaaL kuolltje may have been influenced by the noun guolldo 'strong wind which blows snow up from the ground' $(<* k u o l t \bar{o})$.

\subsection{6.}

SaaN guоти (GenSg gubmo) 'chyme (in the stomach of an animal)' (S-T; YSS 518) < PS *kuomōj < PreS *kamoj $(?<* k a m a-w)$

$<$ NwGerm *kāma- (> Icelandic kám 'dirt, filth') (ÍO s.v. kám) 
The common Saami word *kuomōj 'chyme (in the stomach of animals)' can be derived from PreS *kamoj (? < earlier *kamaw) and thus compared to NwGerm *kāma- (> Icelandic kám 'dirt, filth'). The Icelandic word has been further equated with German Kahm $\sim$ Kahn 'film of mould (on wine)' (ÍO s.v. kám), but this word is better explained as a Romance loan (Kluge s.v. Kahm).

The loan etymology of SaaN guоти is phonologically quite transparent. The ending ${ }^{*}-\bar{o} j\left(<*_{-} w\right)$ is a suffix of unclear function that is attested in many denominal formations, e.g. SaaN guottu 'tree stump' $\sim$ Finn. kanto id. $<*$ kantoj $<$ Proto-Uralic *kïnta-w (cf. Finn. kanta 'base', Western Mansi kẹnt 'pillar of a storehouse' < Proto-Uralic *kïnta). The assumed semantic development 'dirt, filth' > 'chyme' is quite transparent; cf. Finn. rapa 'mud, sludge; dregs; chyme; (dial.) dirt (in e.g. clothes), filth', and Finn. totku 'fish guts; (dial. also) dirt, filth, rubbish' SaaN duotka 'chyme'.

Icelandic kám is related to the Old Norse adjective kámr 'dark, dirty' (< NwGerm *kāma-z), which was also borrowed into Saami, but only after the shift $* a>* u o$ : cf. SaaN gámis 'dark and weatherbeaten (of skin, face)'. It is also possible that SaaL giemes 'twilight' ultimately derives from the same Germanic word (see 3.25.).

\subsection{7.}

SaaN guovla 'overhanging snowdrift', SaaSk kuõbll 'overhanging snowdrift; cliff' (S-T; YSS 527) < PS *kuoplë < PreS *kapli

$<$ PGerm *skabalō- (> Old Norse and Icelandic skafl 'snowdrift; surge, breaker', Faroese skalvur 'heap of snow', Norwegian skavl 'snowdrift') (ÍO, AEWb s.v. skafl)

The common Saami word *kuoplë 'overhanging snowdrift' has no established etymology. In Aikio $(2004: 12,16)$ it was suggested that this word may belong to the stratum of Palaeo-European substrate loanwords of Saami; the suggestion was based on the lack of a known etymology as well as the non-Uralic cluster *-pl- which suggests foreign origin. A straightforward Germanic loan etymology can be presented, though. The word regularly reflects PreS *kapli (also *kopli would be possible) and can be compared to PGerm *skabalo-, which is reflected in the Old Norse and Icelandic skafl 'snowdrift', Faroese skalvur 'heap of snow' and modern Norwegian skavl 'snowdrift'. The same Scandinavian word has also later been reborrowed in Saami, cf. SaaN skálvi 'snowdrift'. The origin of the Scandinavian word family itself is obscure, however; it has been suggested that *skabalo- 'snowdrift' is originally the same word as the homonymous *skabalō- 'scraper' (> German Schabel, Icelandic skafl etc.; a derivative of PGerm *skaba- 'scrape'), but this seems unlikely on semantic grounds. 
The loan etymology of SaaN guovla presupposes that a syncope took place at the time of borrowing. There are many parallels for this, e.g. SaaN (dial.) dordnu 'door' < PreS *turno < PGerm *durōn- (> Gothic daurons 'door(s)') (cf. Sammallahti 1999: 78), SaaN guovlat 'to peep, peek' < PreS *kakli- < PGerm *kagulō- id., and SaaL nuobrre 'the thin innermost part of birch-bark' < PreS *napra < NwGerm *näbirō- 'birch-bark' (see 3.18., 3.20.). There are also similar cases among the Baltic loanwords of Finnic, cf. Finn. rihma 'thread, snare' $<$ PreF * rišma $<$ Baltic *rišima- ( $>$ Lithuanian rišimas 'tying, binding'), Finn. vehma-ro 'pole of a team of draught oxen' $<$ PreF *vešma- < Baltic *vežima- (> Lithuanian vežimas 'waggon') (Koivulehto 2002: 584). The reason for the syncope is probably euphony: ${ }^{*}(C) V(C) C V$ - is a canonic shape for underived roots in Sami and Finnic, whereas * $(C) V C V C(V)$ - is not.

There is also another very similar word in South and Ume Saami. In addition to the regular cognates SaaS goeble 'depression in a mountain side, in which snow remains long unmelted in the spring' and SaaU guab'la 'cliff, precipice' (< PS *kuoplë), there is also a form *koaplē reflected in SaaS gåeblie 'precipice; overhanging snowdrift' and SaaU gà̀b'lee 'cliff, precipice'. The relationship between these two words remains obscure (cf. Aikio 2004: 16); the form *koaple cannot be regularly explained as a borrowing from any Germanic or Scandinavian form. As also northern Germanic *skabalō- 'snowdrift' lacks a clear Indo-European etymology, an ultimate substrate background as suggested in Aikio (o.c.) still remains in principle possible.

3.18.

SaaN guovlat 'to peep, peek' (S-T; YSS 541) < PS *kuovlë- < PreS *kakli-

$<$ PGerm *kagulō- (> Old Norse kogla 'to peep, peek', Icelandic kögla 'to peep, peek, take a look around') (ÍO s.v kögla; AEWb s.v. kogla)

The verb *kuovlë- 'to peep, peek' is attested in all Saami languages. No etymology has been proposed for it. However, it strikingly resembles Old Norse kogla, which has an identical meaning. A direct borrowing from Old Norse cannot be assumed, though, because Saami *-uo- would not have been substituted for open $Q$.

The Norse word reflects PGerm *kagulo-, which is a derivative of a root *kagV- (> Old Norse and Icelandic kaga 'to peek, look around'). This suits perfectly as the original of the Saami word: PS *kuovlë- can be derived from PreS *kakli-, which in turn was borrowed from Germanic *kagulō-. The change PreS $* k l>$ PS $* v l$ is regular, cf. SaaN duovli 'tinder' $\sim$ Finn. taula id. $<*$ takla $<$ Baltic *dagla- (> Latvian dagla 'tinder'). The substitution of a PreS $* i$-stem for a Germanic $* \bar{o}$-stem occurs in several other borrowed verbs, too (see 3.2., 3.8., 
3.10., 3.22. and 3.26. for parallels). The syncope of the second-syllable vowel is motivated by (Pre-) Saami root structure, see 3.17. for discussion and parallels.

3.19.

SaaS moenedh 'to say, mention', SaaU muannat 'to guess (esp. riddles)' (S-N; YSS 690) < PS * mиопё- $(\sim$ irreg. *moanë- $)<$ PreS *mani-

$<$ PGerm *man- (> Gothic man 'I think, I believe', ga-man 'I remember', Old Norse man 'I remember') or *man- $\bar{o}-$ ( $>$ German mahnen 'to remind', Anglo-Saxon ge-monian 'to admonish, exhort, remind'). (Kluge s.v. mahnen; ASD s.v. ge-monian)

The Proto-Saami form *muonë- has regular reflexes from South to Pite Saami, cf. e.g. SaaS moenedh 'to say, mention'. In Lule and North Saami the word shows an irregular diphthong -oa-, cf. SaaL moannat 'to guess', SaaN (obsolete) moannat 'to guess, mention'. The background of the irregularity is unclear, but doubtlessly the two forms are etymologically connected.

In early etymological works the Saami words have been equated with various similar words in other Finno-Ugric languages: Finn. manata 'to conjure; to curse', Mordvin muńams 'to conjure', Mari manam 'I say, utter', Hungarian mond 'to say, utter' and Proto-Samoyed *må(n)- 'to say'. In later works this equation has been doubted due to the irregular sound correspondences. SSA (s.v. manata) states that the proposed Saami, Mordvin and Mari cognates are rejectable on phonological grounds and also the comparison to Hungarian and Samoyed is highly uncertain. To this one can add that Hungarian -o- cannot correspond to Finnish $-a$-, and the irregular variation between $*_{-} n$ - and $-\varnothing$ - in the Samoyed forms (see Janhunen 1977: 88) is also highly problematic. UEW (290-291), too, considers the Finno-Ugric equation very uncertain; this dictionary also includes a peculiar reference to the onomatopoietic (!) nature of the words.

There are thus no grounds for connecting the Saami word family with any Uralic parallels. Instead, it can be explained as a Germanic loan. The form *muonë- attested from South to Pite Saami reflects PreS *mani- (also *moni- or *mōni- are theoretically possible); the presumably secondary form *moanë- in Lule and North Saami shows an unetymological vowel combination and cannot thus regularly reflect any Pre-Saami form. The form *mani- strikingly resembles PGerm *man-, attested in such forms as Gothic man 'I think, I believe' and Old Norse man 'I remember'. PGerm *man- derives from the Indo-European root *men- 'to think, remember'; it was originally a fossilised perfect form reflecting Indo-European *(me-)mona (> Greek mé-mona 'I intend to'), with regular loss of reduplication in Germanic (J. Koivulehto, p.c.; cf. Kluge s.v. mahnen). Another possible source of the Saami word is the derived verb 
*man-o-, which is reflected in German mahnen 'to remind' and Anglo-Saxon ge-monian. Both of these alternatives are semantically straightforward: it is easy to imagine either a semantic shift 'to remember' $>$ 'to guess (e.g. a riddle)' ( $>$ 'to say, mention') or 'to remind' > 'to say, mention' ( $>$ 'to guess').

As regards the other Finno-Ugric words, at least Finnish manata 'to conjure; to curse' must be a separate borrowing from the same Germanic family; note that the same meaning 'to conjure' is also attested in Old Swedish mana, which was borrowed from Middle Low German (cf. SSA s.v. manata, where the Germanic loan etymology is considered uncertain). The Saami and Finnish items cannot be cognate because their second syllable vowels do not match. Also some of the similar words in the more eastern Uralic languages might derive in one way or the other from Indo-European, but this possibility is not studied further here.

3.20 .

SaaL nuobrre $\sim$ nuobrre-bies'se 'the thin innermost part of birch-bark' (bies'se 'birch-bark') (not attested elsewhere in Saami) < PS *nuoprē < PreS *napra

$<$ NwGerm *nābirō- 'birch-bark' (> Old Norse noefr, Icelandic naefur, Swedish näver, etc.) (ÍO s.v. næefur; AEWb s.v. nœefr; SEO s.v. näver)

SaaL nuobrre has no cognates elsewhere in Saami. However, the word would regularly reflect PreS *napra, which strikingly resembles a Scandinavian word family whose meaning is 'birch-bark': Old Norse nafr, Icelandic nafur, Swedish näver, etc. The protoform of this word has usually been reconstructed as PGerm *nēbizō- or the like (ÍO s.v. naefur; AEWb s.v. nœefr). However, it is not necessary to reconstruct $*_{z}$ : the word is not attested outside Scandinavian, and it is not possible to distinguish between PGerm ${ }^{*} z$ and ${ }^{*} r$ on the basis of the attested reflexes. Indeed, Hellquist provides the alternative reconstructions *nēbiz(i)ō- and *nēbirō- (SEO s.v. näver). SaaL nuobrre < *napra lends support to the reconstruction of $*$, as the word can be quite straightforwardly derived from NwGerm *nābirō- $(\mathrm{NwGerm} * \bar{a}<$ PGerm $* \bar{e})$. The syncope of the vowel *-i- is motivated by euphony; see 3.17 . for parallels and discussion. Also, the semantic correspondence between Saami and Scandinavian is quite close. 
3.21.

SaaS roevtedh 'to become sunburnt' (not attested elsewhere in Saami) $<$ PS

*ruovtë- $<$ PreS *rawti-

$<$ PGerm * raudē- (> Middle High German rōten 'to become red', cf. modern German er-röten 'to blush, flush, become red'), a derivative of PGerm *rauda- 'red' (> German rot, English red, Icelandic rauður, etc.) (ÍO s.v. rauður; Kluge s.v. rot; VA s.v. rød; SEO s.v. röd)

South Saami roevtedh 'to become sunburnt' does not have cognates elsewhere in Saami, but it can be regularly projected back to PreS * rawti- (theoretically also *rowti-). The word is obviously connected with PGerm *rauda- 'red'. The exact loan original was probably the derived verb * raud- $\bar{e}-$, which is reflected in Middle High German rōten 'to become red' (this verb was pointed out to me by J. Koivulehto, p.c.). The loan etymology is both semantically and phonologically quite self-evident.

\subsection{2 .}

SaaN ruossat 'to stumble', SaaI ruossâd 'to stumble; to rush somewhere', SaaS roesedh 'to fall dead (of animals)' (S, L-I) < PS *ruosë- < PreS *rasi-

$<$ PGerm *rasō- (> Old Norse and Icelandic rasa 'to rush; to stumble'); cf. also PGerm *rēsō- > NwGerm *rāsō- (> Icelandic rása 'to run around') (ÍO s.v. rás, rasa ${ }^{1}$, rasa ${ }^{2}$; AEWb s.v. rasa; VA s.v. rase; SEO s.v. rasa)

SaaN ruossat and its cognates in other Saami languages have not been discussed in etymological literature. The verb goes back regularly to PreS *rasi(in principle also *rosi- and *rōsi- would be possible), and it can thus be derived from PGerm *rasō- 'to rush; to stumble'. The etymology is semantically impeccable: both meanings of the Germanic verb are attested in Saami as well. The sound correspondence between the forms is also quite regular. Concerning the PreS $* i$-stem in the place of a Germanic ${ }^{*} \bar{o}$-stem, see 3.2., 3.8., 3.10., 3.18. and 3.26. for parallels.

An alternative possibility is that the Saami word derives from the related NwGerm verb * rāsō- (<PGerm *rēsō-), which is reflected in Icelandic rása 'to run around', German rasen 'to race, speed; to rage, foam, storm'. On semantic grounds this is less likely, though, as its reflexes do not have the meaning 'to stumble'. On the other hand, it seems that the PGerm form *rēsō- has been borrowed into Finnic: cf. Finnish riehua 'to rage; to storm; to act wildly, to romp about' < PreF * rēšu- (note that SSA (s.v.) classifies this word as "descriptive"). 
3.23 .

SaaP ruos'sjie 'a hard grass with which wooden vessels are scrubbed' (not attested elsewhere in Saami) $<$ PS * ruošš $\bar{e}<$ PreS * rasja

$<$ PGerm *grasja- 'grass' ( $>$ Swedish gräs, Danish graes), a derivative of PGerm *grasa- 'grass' (> Icelandic gras, German Gras, English grass, etc.) (ÍO s.v. gras; SEO s.v. gräs; Kluge s.v. Gras)

Pite Saami ruos'sjie does not have cognates elsewhere in Saami. There is a similar word in Sammallahti's North Saami dictionary (1989), SaaN ruoššsi 'common reed', 11 but this item is not a true cognate because it is a neologism that has been constructed by Samuli Aikio on the basis of the Pite Saami word. Despite its narrow distribution, SaaP ruos'sjie can be regularly derived from PS * ruošše $<$ PreS *rasja, and thus explained as a loan from PGerm *grasja- 'grass'; the etymology is quite obvious both phonologically and semantically. This derivative is attested in Swedish gräs and Danish groes (note also Norwegian gress < Danish), whereas the other Germanic languages show reflexes of the underived root*grasa-. The form * grasja- has been explained as a 'collective formation' (SEO s.v. gräs) or "tilhørighetsdannelse" (VA s.v. gras) of *grasa-.

3.24 .

SaaS soegkes 'roasted too hard (of coffee); burnt (of porridge)', suegkiedidh 'to smell burnt', såagkodh 'to become burnt' (not attested elsewhere in Saami), derivatives of PS *suoyke- $<$ PreS *sayka-

$<$ PGerm *sanga- (> Icelandic sangur 'burnt (e.g. of porridge)'); cf. the derivative *sangja- ( $>$ Icelandic sengja 'to let burn', German sengen 'to singe', English singe) (ÍO s.v. sangur; cf. Kluge s.v. sengen, where the Icelandic cognates have been omitted)

This South Saami word family has no cognates elsewhere in Saami, but it can be regularly derived from a Pre-Saami root*sayka-. This is an obvious borrowing from PGerm *sanga-, which is reflected in Icelandic sangur 'burnt'. There is also a derived verb *sangja- 'to let burn, to singe', which shows more widespread reflexes in Germanic. The loan etymology is both phonologically and semantically exact. 


\subsection{5 .}

SaaSk teä'mes 'dark, dim' (?N, Sk-K) < PS *teamēe(-s) and SaaN deavkat 'dim', SaaT temkkas 'dark, cloudy (of day, weather)' (N-Sk, T) $<$ PS *teamkkV- <<*team $V-k k V-<$ PreS *temä $(-s)$

$<$ PGerm *bemaz- (> Old High German demar 'twilight, dusk') (Kluge s.v. Dämmer; VA s.v. demre)

The common Saami adjective for 'dark' is *seavnéte (> SaaN seavdnjat etc.), which is of unknown origin. However, in SaaSk a parallel word teä'mes 'dark' is also known. This word goes regularly back to PS *teamess and PreS *temäs. In Kildin Saami the same word-stem is attested with a different adjective suffix: SaaK tiemma $\delta$ (< PS *team-ëtē). A semantically and phonologically exact loan original for these words is provided by PGerm *bemaz-, reflected in Old High German demar 'twilight, dusk'. The Germanic word derives from IndoEuropean *tem-es- / *tem-os- (> Old Indic támas- 'darkness'; Latin tenebrae id. $<*$ temes-rā); cf. also Russian тёмный 'dark' (<*temeno-), Lithuanian témti 'to become dark' $(<*$ tem-), etc. The borrowing must be quite old due to the PS $*_{-} e a-$, which is the reflex for Germanic $*_{-} e-$; see 3.7. and 3.12. for parallels for this correspondence.

The same root *teame $\bar{e}(-s)$ is also attested in an obscured derivative *teamkke (> SaaI tevkki 'cirrus (cloud)') and its further adjective formations *teamkk-ëtē (> SaaN deavkat 'dim', SaaSk teukkâd 'dark, cloudy (of day, weather)') and *teamkk-ōs (> SaaT temkkas id.). The last form demonstrates that the word originally contained the rather unusual PS cluster *-mkk-, which in this case arose through an irregular syncope from an earlier form *teamV-kke. An exact phonological parallel for such a syncope occurs in SaaS humhkie 'dark, snowy weather in daytime, in which the terrain looks level' $(<*$ humkkē $<*$ humë-kkē), cf. SaaS hovme 'snowfall, snowstorm' (<*humë). There are also many similar cases of syncope after the liquids $l$ and $r$; cf. e.g. SaaN njaláhas njalkkas 'slippery' (< *nélākkës *'éelkkës), SaaN bálkestit 'to throw (one item)', bálkut 'to throw (many items)' (< *pālkkV-) bállahastit 'to throw (an item at something)', bállat 'an item to throw at something' (< *pāllëkkēe(-)), and SaaN vuoražas 'crow', SaaU vuarahtjis id. $(<*$ vuorëččVs)

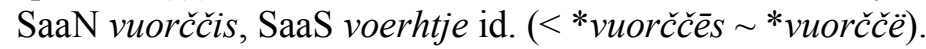

There is also a third word in North and Inari Saami that resembles the PS root *teamē-: SaaN deamádat geamádat 'misty weather in winter', SaaI kiämádâh 'twilight' (<*keamā-ntëk $\sim{ }^{*} t$-). The SaaN form deamádat could be easily explained as a derivative formed from PS *teame-; the suffix -ádat forms nouns denoting natural conditions (cf. e.g. SaaN beaivv-ádat 'sunshine' < beaivi 'sun; day', čielgg-ádat 'clear, bright weather' < čielggas 'clear', goikk-ádat 'drought' < goikkis 'dry'). However, the variation of the initial consonant $\left({ }^{*} t-\sim\right.$ 
$*_{k-)}$ is irregular. The most likely explanation for this oscillation is a contamination of two distinct Saami word families: *teamēs (> SaaSk teä'mes 'dark') and *keamēs (> SaaL giemes 'twilight', SaaI kiämá-dâh id.).

No etymology has been presented for the latter word, but one can cautiosly propose Germanic origin: cf. PGerm *kēma-z $>$ NwGerm *kāma-z> Old Norse kámr 'dark, dirty'. A later Proto-Scandinavian borrowing from this word is SaaN gámis 'dark and weatherbeaten (of skin, face)'. The Germanic word is etymologically connected with Icelandic kám 'dirt, filth', which is also reflected in another loanword that has participated in the shift $* a>u o$, SaaN guomu 'chyme' (see 3.16). However, the Germanic origin of SaaL giemes ( $<$ PS *keamēs) remains uncertain, as one would rather expect PS *-ie- in the place of PGerm *-ē-: cf. e.g. SaaN lieđđi 'flower, blossom' < PreS *lē $\ddot{a}<$ PGerm *blèda- (> Old English blōed 'flower, blossom; fruit') and SaaN viehku 'an old measure of weight (18 kilogrammes)' < PreS *wēko < PGerm *wēgō- (> Old Norse vág 'scales; a measure of weight (10 kilogrammes)').

3.26 .

SaaN vuorjat 'to pester, act as a nuisance; to trouble, worry' $(\mathrm{N}-\mathrm{K})<\mathrm{PS}$ *vuorjë- < PreS *arji-

< PGerm *harjō- (> Old Norse herja 'to harry, plunder; to wage war', German ver-heeren 'to destroy, lay waste', English harry) (ÍO s.v. her; AEWb s.v. herja; SEO s.v. här $r^{3}$ )

PS *vuorjë- has reflexes from North Saami to Kildin Saami. All show approximately the same meaning 'to trouble, pester, act as a nuisance'. The word can be projected back to PreS *arji- (*warji- and * orji- are also theoretically possible), which gives a reason to compare it to PGerm *harjo- 'to harry, plunder, etc.'. The Germanic word is a derivative of *harja- 'troop, armed band' ( $>$ German Heer, Icelandic her). The etymology is phonologically regular; PreS Øhas been substituted for PGerm $* h$ - in several other borrowings, too (see section 2 ). Germanic $* \bar{o}$-stem verbs have often been nativised as $* i$-stems in Pre-Saami (see 3.2., 3.8., 3.10., 3.18. and 3.22. for parallels).

At first sight the semantics of the Saami and Germanic items would seem to be quite far from each other. However, exactly the same semantic development that must be assumed for Saami has taken place in English. The verb harry has, in addition to its inherited primary meanings 'to perform military raids; to overrun with an army, to lay waste, to pillage', also developed the senses 'to worry, goad, torment, harrass; to maltreat, ill-use; to worry mentally'; cf. such examples as That your mind should be harried it is no wonder (1764), He was haunted and harried with the horrible apparations and spectres of Furies (1609), and Why do you harye the poore felowe on this facyon? (1530) 
(OED s.v. harry). Such usage is certainly an innovation of English and not a retention from Proto-Germanic, but it still serves as a perfect parallel for the assumed semantic development of the Saami word. Other examples of similar semantic shifts can also be cited: cf. Finn. vainota 'to persecute; (coll.) to harass' < vaino 'persecution; (dial.) war' < Russian война 'war' (this etymology is needlessly considered uncertain in SSA s.v.); German stören 'to disturb' (cf. zer-stören 'to destroy') < Old High German stōren 'to scatter, destroy' (Kluge s.v.), English disturb < Latin disturbo 'to drive asunder, to separate by violence; to throw into disorder, to disturb' (CEDEL s.v.), SaaN hehttet 'to hinder, impede, disturb' < Finn. häätää 'to drive away' Ludic hiättä 'to drive away; to destroy; to kill'. ${ }^{12}$

\subsection{7 .}

SaaS vuerie 'consciousness, senses', (der.) vueries 'sober, one who is in his right mind', (?) våaroes 'alert, shy, cautious (of birds, fish)' (not attested elsewhere in Saami) $<$ PS *vuore $<$ PreS *wara (? Finn. vara 'attentiveness; room, allowance; spare, extra, etc.')

$<$ PGerm *wara- (> Icelandic var 'one who is attentive, careful, cautious', Gothic vars 'careful, cautious', German ge-wahr 'aware', English a-ware, war-y) (ÍO, VA s.v. var; SEO s.v. var ; Kluge s.v. gewahr)

Finn. vara 'attentiveness, etc.' is generally recognised as a Germanic loanword, cf. PGerm *wara- 'attentive, careful, cautious'. However, these words have not been previously compared to SaaS vuerie 'consciousness, senses', which would be the regular cognate of Finn. vara. The Saami word evidently derives from the same Germanic source; the semantic connection between 'consciousness, senses' and 'attention, care, caution' is quite transparent. It is impossible, though, to resolve whether the South Saami and Finnic items are true cognates or separate borrowings from the same Germanic word.

There is also a word våaroes 'alert, shy, cautious (of birds and fish)' (< *vuorōs) in South Saami, which looks very much like a derivative of the root *vuore ; here the semantics come even closer to the assumed Germanic loan original. However, it seems that this word is at least secondarily connected to another Saami word family, PS *oarve $\sim$ *vuorve $(-s)>$ SaaP vuorvies 'shy (of birds)', SaaL vuorvve oarvve id., SaaSk vuä'rvv 'restless, skittish (e.g. of draught reindeer), shy'. This cognate set shows unexplained alteration between *oa- (> SaaL oarvve, SaaSk) and *vuo- (> SaaP, SaaL vuorvve). It seems that SaaS våaroes has been at least semantically influenced by *vuorvēs (> SaaP vuorvies), even if it is originally a derivative of *vuore.

Also, SaaN várveš 'sharp-sighted, sharp-eared' (< PS *vārviš) resembles the Pite, Lule and Skolt Saami words mentioned above. However, the 
relationship between this word and PS *oarve $\sim$ *vuorve is obscure, and the origin of both items is unknown. They come semantically close to the Germanic word family, and the initial *vuor- and *vār- would correspond well to Germanic *wara-. Still, no loan original can be reconstructed which would explain the consonant cluster $*_{-} r v$ - in Saami, so the correspondence may be merely coincidental. The PS form *vuorve $\sim$ *oarve has also been adopted as a substrate borrowing into Finnish and Karelian, cf. Finn. dial. vorva 'light sleeper; one who is on the alert, on one's guard' (SKES s.v.).

\section{Saami prehistory in the light of language contacts}

The study in the previous section reveals that the Germanic influence on Pre-Saami has been stronger than thought by previous research: there are many previously undiscovered loanwords that display reflexes of Pre-Saami sound changes, in particular the vowel shift PreS $* a>$ PS *uo. The lexical material also reinforces the view that Saami has adopted most of its early Germanic loanwords independently of Finnic. Only four of the 27 Saami words etymologised, SaaN boldni 'hillock, mound' (3.4.), borsi 'foaming rapids in a canyon' (3.5.), geardni 'thin, frozen snow-crust' (3.12.) and SaaS vuerie 'consciousness, senses' (3.27.), have a possible cognate in Finnic. Even in these cases the corresponding Finnic item may either have been separately borrowed or, in the case of geardni, be etymologically unrelated.

The sound change $* a>* u o$ is of particular interest for the dating of contacts between Germanic and Pre-Saami. It is noteworthy that this Saami sound change has also occurred in loanwords reflecting NwGerm $* \bar{a}(<\mathrm{PGerm} * \bar{e})$, as demonstrated by such borrowings as SaaN vuohčču 'narrow, wet bog', vuoksa 'depth of a fishing net' (see section 2), guоти 'chyme (in an animal's stomach)' (3.16.) and SaaL nuobrre 'the innermost part of birch-bark' (3.20.). As pointed out by Koivulehto (1999a: 14-15, 260, 271, 364-365, 372), this suggests that the shift $* \bar{e}>* \bar{a}$ took place relatively early in the northern dialect(s) of ProtoGermanic. Even so, this still seems to imply that the Saami vowel change $* a>$ *uo is relatively recent, probably only dating back to the early period of the Iron Age. The terminus ante quem of the shift $* \bar{e}>* \bar{a}$ is 100 A.D., as the earliest Germanic runic inscriptions already display this change. But as pointed out by Kallio (2006: 14), the change can hardly be very much older either, as the early runic inscriptions are otherwise still not very far from Proto-Germanic phonology. A further clue is provided by SaaN ruovdi 'iron' $(<\mathrm{PreS} *$ rawta $<$ PGerm *raudan-), which indicates that the shift $* a>* u o$ must have taken place after the introduction of iron.

An early Iron-Age dating of the Saami vowel shift $* a>* u o$ is also consistent with the high number of Germanic loanwords that have participated in the change. Adding up the previously known examples listed in section 2 (25) and 
the new cases discussed in section 3 (18), their number is at least 43. If the development $* a>* u o$ were very old one would hardly expect to find so many loanwords that have participated in this change.

The late dating of the change $* a>*^{*} u$ has notable chronological implications for the development of the entire Proto-Saami vowel system. The vowel shifts that took place in Proto-Saami seem to involve a chain reaction set in motion by a small number of changes, a typical feature in the development of vowel systems. Known parallels such as the Great English Vowel Shift and the Northern Cities Shift (in certain dialects of American English) suggest that the completion of a chain shift is a matter of decades rather than centuries, and hence it is likely that also 'the great Saami vowel shift' took place during a relatively short period. As the change PreS $* a>* \bar{o}$ ( $>$ PS $* u o$ ) must in terms of internal chronology be one of the earliest changes that took place in the PreS system (cf. Korhonen 1981: 71-; Sammallahti 1998: 181-189), and because this change can hardly be older than the early Iron Age, it seems that Pre-Saami remained quite conservative in respect to its vocalism for a long time.

From the point of view of Saami ethnic history, it is of particular interest to examine where these vowel shifts were accomplished and where the Germanic contacts preceding them took place - i.e., to locate the "homeland" wherein Proto-Saami in the proper sense first emerged. But the Germanic loanwords alone do not yet reveal the geographical setting of the contacts. To build a more coherent picture of the emergence of Saami languages in terms of space and time, the results must be compared with evidence of interaction between the Saami and other language groups.

At present there is a wealth of evidence for the traditional view that the original core area of Proto-Saami was located somewhere in the southern parts of Finland and Karelia. It has for long been recognised that both oral tradition and the historical record testify to Saami inhabitation in these areas in the Middle and Early Modern Ages (T. I. Itkonen 1947). In this area one also finds an extensive stratum of substrate toponyms that display both lexically and phonologically distinctively Saami features (Aikio in press b; Saarikivi 2004b). It is also known that there are Saami substrate loanwords in the southern dialects of Finnish (see e.g. O. Korhonen 1979b; Koponen 1996), even though this lexical stratum has not been very thoroughly studied. ${ }^{13}$

The southern origin of Proto-Saami is supported by the loanword strata that are present in Saami. There are some independent Baltic borrowings in Saami, such as SaaN biebmat 'to feed', giehpa 'soot', leaibi 'alder', vietka 'adze', vuoras 'old (of persons)' and SaaS saertie 'reindeer heart (as food)' (T. I. Itkonen 1958: 751; Sammallahti 1984: 139; Koivulehto 1992). However, the total number of such loans is apparently much smaller than that of the old Germanic loanwords, which suggests that the majority of Baltic loans in Saami were mediated by Finnic. However, this still implies early loan contacts with 
the Pre-stages of Finnic, of which there is ample lexical evidence. Contacts preceding the Proto-Finnic stage are proved e.g. by the presence of loanwords adopted before the shift $\operatorname{PreF} * \check{s}>\mathrm{PF} * h$; consider the following examples:

- SaaN buošši 'bad-tempered (of a woman)' < PS *puoše $<<$ PreF *paša (> Finn. paha 'bad; evil')

- SaaN duššsi 'trifle, nothing' < PS *tuššse << PreF *tüšjä (> Finn. tyhjä 'empty; trifle')

- SaaN láššsi 'thin, meager' < PS *lāšše $<<$ PreF *lajša (> Finn. laiha 'thin, meager')

- SaaL sjabme 'joy' < PS *šëmēe $<<$ PreF *šimo (*šima?) (> Finn. himo 'lust, desire, craving')

- SaaS sjïjle 'glowing coal' < PS *šilë << PreF *šlli (> Finn. hiili 'coal')

- SaaI šišne 'tanned leather' < PS *šišne $<<$ PreF *šišna (> Finn. hihna 'leather strap')

- SaaK šuvv 'good, excellent' < PS *̌̌uvë << PreF *šüvä (> Finn. hyvä 'good')

- SaaSk vââ̌šs 'thicket with young pine trees' < PS *vëšo $<<\operatorname{PreF} * v i \check{a} a-(>$ Finn. viha-nta 'green, lush'); this word was erroneously listed as a possible Palaeo-European substrate item in Aikio (2004: 11-12).

- SaaN vašši 'hatred' $<$ PS * vëše $<<$ PreF *viša (> Finn. viha 'hatred')

The examples above represent only a small fraction of the vocabulary that was adopted into Pre-Saami from Pre-Finnic. The etymological analysis of this loanword stratum involves particular problems, though, as it is often difficult to distinguish such early borrowings from true cognate items. Five of the loanwords in the list above display regular vowel correspondence, and borrowing can only be detected due to the lucky fact that the word happens to contain the sibilant $* s$ : common inherited items display the correspondence PF $* h \sim \mathrm{PS} * s$, and thus $\mathrm{PF} * h \sim \mathrm{PS} * s$ is indicative of borrowing. But the bulk of the common Finnic-Saami vocabulary contains no comparable phonological criteria for distinguishing early loanwords from true cognates. Sammallahti (1999: 74) reports that the number of common Finnic-Saami words which lack further Uralic cognates is 280 , and it seems evident that this figure includes a high number of quasi-cognates which display regular sound correspondence even though they have diffused between the two already diverged idioms. Moreover, the process of 'etymological nativisation' has certainly also played a role in the emergence of such word pairs whose cognation is only apparent (see Aikio in press a).

Despite the problems involved in the analysis of individual items the existence of Pre-Finnic loanwords in Saami cannot be doubted. Finnic had appar- 
ently been confined to its original home in the vicinity of the Gulf of Finland until its disintegration in the Iron Age, and this implies that Saami also must have originally developed at a relatively southern latitude - if the Saami homeland had been located in Lapland, no Pre-Finnic (or Baltic) loans would be present in the Saami languages. One can assume that Proto-Saami emerged somewhere within the area where numerous Saami substrate toponyms are attested, stretching from southern Finland in the west to the great lakes Ladoga and Onega in the east; this placement allows for the possibility of direct contact with Proto-Finnic, which was perhaps spoken along the southern shore as well as at the bottom of the Gulf of Finland.

The Gulf of Finland also provides a nautical route via which early Germanic influence must have spread to both Finnic and Saami, along with the Nordic Bronze Age culture whose impact can be seen in southwestern Finland and in Estonia (cf. e.g. Carpelan \& Parpola 2001: 90-91). Indeed, this seems to be the only plausible way to explain the adoption of Proto-Germanic loanwords into Pre-Saami; as these contacts date back to the Late Bronze Age and the Early Iron Age, they could hardly have taken place in the northern parts of Fennoscandia where nothing points to a Germanic presence before the Nordic period. Thus, one can conclude that the earliest Germanic loanwords were adopted in the southerly homeland quite far from the present area in which Saami is spoken.

While the rough placement of the Saami homeland is quite clear, it seems to be impossible to determine its exact location in the light of present research. Saarikivi (2004b) has suggested on the basis of the distribution of Saami substrate place-name elements that the first formation area of Pre-Saami was located south of Lake Ladoga and Lake Onega, and this idea might receive some support from the presence of phonologically abnormal types of Saami substrate place-names in the same region (cf. Mullonen 2002 passim). Such names could represent the traces of extinct Para-Saami idioms, i.e. languages closely related to Proto-Saami. If such have existed in the region, it is also likely that the formation of Proto-Saami in the proper sense took place in the vicinity. On the other hand, the postulation of a homeland east of the bottom of the Gulf of Finland would seem to make it more difficult to explain the contacts with ProtoGermanic, for which southern Finland provides a more likely setting.

We can also estimate the original geographical extent of the Saami homeland. One can disregard the notion that Proto-Saami and Pre-Saami were originally spoken both in Lapland on the one hand and in Southern Finland and Karelia on the other; such an area is far too wide and geographically diffuse to have been occupied by a single speech community for any period of time, and thus it does not qualify as a possible homeland. Such vast homelands have recently been the fashion in Uralic linguistics, though, and there is no lack of proposals for wide Urheimaten. Even so, it is an ethnographic fact that hunter- 
gatherer cultures are characterised by small speech communities, geographically limited communication networks and often also hostile relations with neighbouring groups - and it is not very fruitful to propose prehistoric scenarios that contradict real-world regularities of linguistic diversity. ${ }^{14}$

In the Middle Ages a vast territory comprising both Lapland and large parts of southern Finland and Karelia was indeed simultaneously inhabited by speakers of Saami languages. This situation can only be the result of linguistic expansion - Proto-Saami must primarily have been spoken in a narrow southern homeland from which it secondarily spread to cover this territory. The differentiation of Proto-Saami into various local Saami languages was a direct result of an expansion which made it impossible to maintain a communication network over the immense area. The disintegration of Proto-Saami can be quite reliably dated to approximately 0-500 A.D. on the basis of the phonology and distribution of Proto-Scandinavian loanwords, which in turn implies that also the expansion of Proto-Saami took place in the early Iron Age (Aikio 2004: 26) - a result which is in harmony with the late dating of the Pre-Saami vowel shifts.

It seems quite certain that prior to the expansion of Saami the linguistic map of Fennoscandia was radically different. The areas into which Saami spread were not uninhabited, and hence extensive language replacement must have taken place. Nine distinct Saami languages are spoken today in Lapland, and even if relatively close varieties with limited mutual comprehensibility (such as South and Ume Saami or North and Lule Saami) were counted as single languages, one would still have to reckon with 5-6 distinct languages. Let us for the sake of argument assume that another five were once spoken in the more southern parts of Finland and Karelia before the subsequent expansion of Finnic pushed them into extinction. This would imply that the historical Saami territory is large enough to uphold at least ten hunter-gatherer speech communitites. But Proto-Saami must originally have developed in only one speech community, and the languages once spoken in the rest, whatever their genetic affiliation must now be extinct.

The considerations above should illustrate the basic error involved in prehistoric scenarios that only operate with the proto-forms of known languages. In recent Finnish research on ethnic history it has become a common practice to place the predecessors of the present day language branches (Proto-Finnic, Proto-Saami, Proto-Germanic, Proto-Baltic, etc.) on the map of Bronze-Age northern Europe so that most or all areas end up being occupied by known language groups. But there is no reason to assume that this part of the world was in prehistoric times occupied by far fewer languages than it has been during known history, and hence such an approach inevitably entails the postulation of unrealistically large prehistoric speech communities. Instead of presenting such hypotheses it should be acknowledged that most of the languages that were spoken in Bronze-Age northern Europe are in all probability now extinct and 
that there are no valid methods for reconstructing the details of the linguistic map of this period; the evidence has been irretrievably lost.

It can, in fact, be verified by linguistic analysis that this is the case. Languages rarely become lost without a trace, as expanding languages are susceptible to substrate influence from the receding idioms. Even in such cases where newcomers have outnumbered the natives and possessed superior technology and weaponry a high number of substrate place-names have been adopted (consider, for instance, North America and Australia). In a demographically more balanced situation where language shift plays a central role substrate influence is likely to be more pervasive. Thus, there is reason to assume that the lost languages of northern Europe have left substrata in the surviving ones - and there are indeed linguistic methods for detecting and analysing this linguistic residue (for a methodological discussion see Salmons 1992; Aikio 2004: 7-10; Saarikivi 2004a).

In the field of Indo-European linguistics it seems to be well-established that there is a 'Palaeo-European' component in the lexicon of the Germanic languages, for instance. In the case of Finnic languages similar views have been put forward by Ariste (e.g. 1971), but in general substrate hypotheses have not gained much attention in Uralic linguistics until recent times. Saarikivi (2004a; 2004b) draws attention to the fact that there are several etymologically opaque words among the central topographic terms of Finnic and Saami. A more detailed analysis of the etymologically opaque part of the Saami lexicon reveals traces of intensive substrate influence from unknown Palaeo-European languages (Aikio 2004). There are hundreds of Saami words which have no known etymology and which belong to semantic domains typical of substrate vocabulary, including words for animals and plants, topographic formations, weather and other natural conditions, and hunting and fishing equipment and methods. What is more, there are also a huge number of etymologically inexplicable place-names, many of which denote major topographic formations.

A phonological analysis of these layers of vocabulary and place-names has yielded evidence for the dating of the language shift. Quite many of the words and names show phonotactic features which secondarily became possible in Proto-Saami and cannot be traced back to any Pre-Saami form preceding 'the great Saami vowel shift'. As an example one can mention unetymological vowel combinations such as SaaN $\dot{a}-a, \dot{a}-u, e a-a$ and $i e-i$, which arose during the separate development of Saami and hence only appear in loanwords but not in inherited Uralic vocabulary. There are numerous etymologically opaque words and place-names in Saami that show such vowel combinations: cf. e.g. SaaN njálla 'arctic fox', ákču 'common seal', čearga 'snowdrift', vieksi 'young common seal', and the mountain names Álla, Gáiku, Bealča, and Čiesti (for more examples see Aikio 2004). 


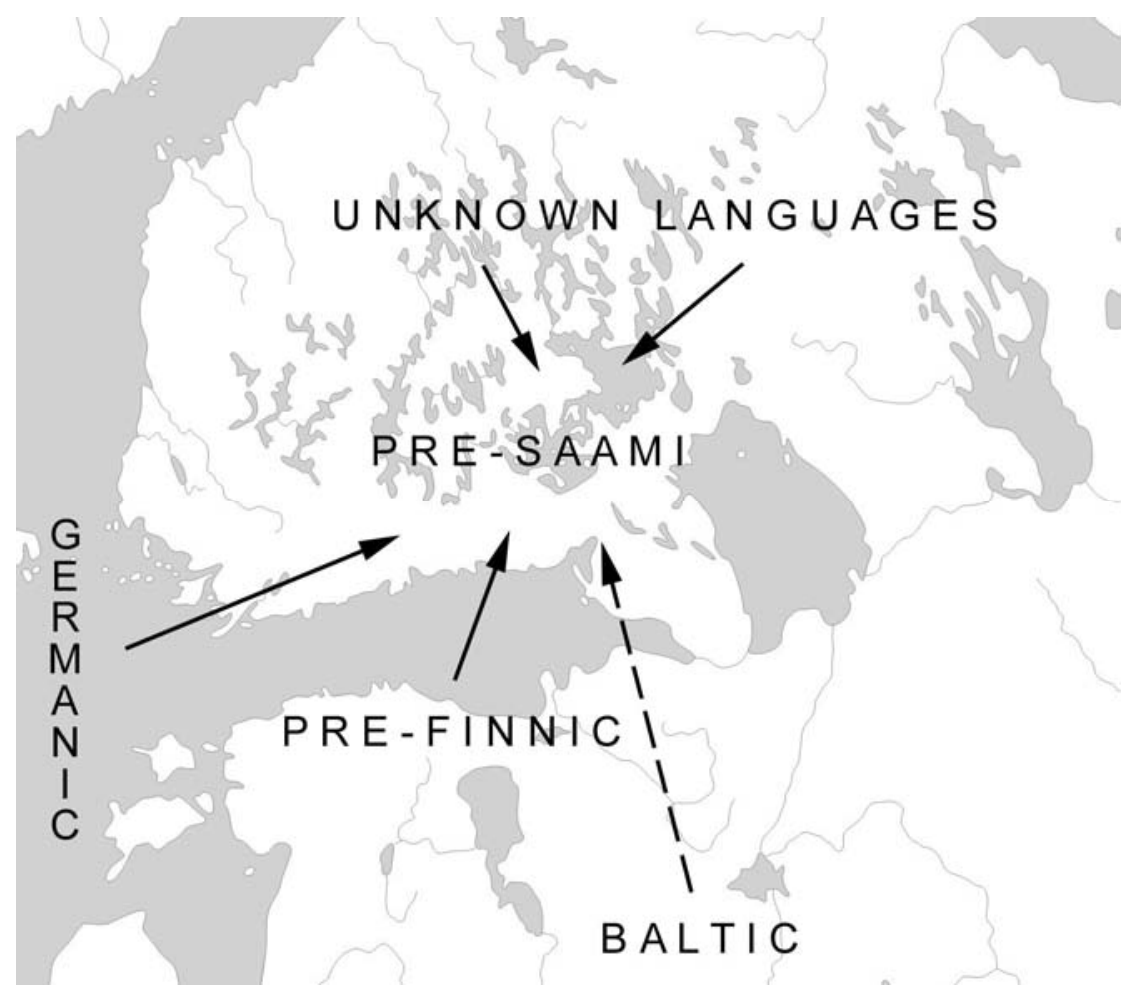

Map 1. The areal context where Pre-Saami developed into Proto-Saami. The locations of the languages are schematic.

Moreover, surprisingly many such words show unexplained irregularities in intra-Saami sound correspondences; cf. e.g. SaaN itku 'shady place' $(<* i t k \bar{o}) \sim$ SaaSk õotkâs id. (<*ëtkës), SaaN duollu 'frost on the ground' $(<*$ tuolō) SaaSk taal id. (<*tālëk), SaaN jassa 'patch of snow (up in the mountains in

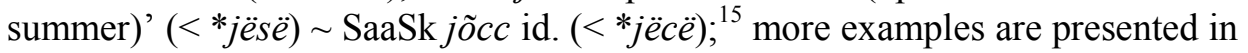
Aikio (2004: 14-16). Words displaying such obscure correspondences cannot derive from the same ancestral form, and this suggests that they are parallel borrowings from distinct but related substrate idioms into a post-Proto-Saami dialect continuum. This result lends support to the hypothesis of a simultaneous spread and divergence of Proto-Saami in the early Iron Age that was suggested above.

One thus arrives at the picture that Proto-Saami originally developed in an area situated between the known Germanic and Finnic language groups and the unknown Palaeo-European cultures of Northern Europe (see Map 1). At present little can be said of the causes of its subsequent expansion, but one can certainly 
imagine that the speakers of Proto-Saami have tried to exploit this intermediate position, e.g. in terms of the fur trade (cf. the case of the Cree mentioned in endnote 14). It might turn out to be fruitful to examine this issue against what is known of the trade relations in the early Iron Age. ${ }^{16}$

Lastly, let us briefly examine how the picture sketched out above correlates with archaeology. Three linguistic findings are of interest here, namely that the Proto-Saami language originally developed outside Lapland, that its expansion to Lapland took place through an abrupt process (a series of language shifts), and that this expansion cannot predate the early Iron Age. These results refute three claims that are frequent in recent archaological research, namely that the Saami ethnos originally developed in Lapland, that this process was gradual, and that there is some type of ethnic continuity between the Bronze Age or even the Stone Age cultures in Lapland and the historical Saami people (see e.g. Huurre 1979: 152-153; Odner 1983 passim; Halinen 1999 and Hansen \& Olsen 2004: 36-42, who subscribe to some or all of these claims).

It is indeed well-known that the archaeological record of Lapland displays a degree of continuity in the material expressions of culture, a fact that has led many scholars to postulate a corresponding ethnolinguistic continuity. As an extreme example one can mention Halinen (1999), who proposes that Lapland must have become Finno-Ugrianised already during the Mesolithic because no mass migration or other abrupt change can be detected in the later archaeological record. But as the very idea of a Mesolithic Saami expansion is a linguistic anachronism, this only serves to illustrate the methodological error involved in this kind of reasoning: a purely archaeological analysis cannot establish any linguistic conclusions, least of all conclusions that contradict those reached through linguistic methods. One can add that similar archaeological 'continuity' can also be demonstrated in many other parts of the world and in most cases it does not correlate with linguistic continuity at all (Mallory 2001: 357-358). ${ }^{17}$

In contrast to such extreme continuity scenarios, the archaeologist Christian Carpelan has during the recent decades developed a more plausible theory of Saami ethnogenesis on the basis of both archaeological and linguistic findings, arguing that the spread of Saami in Lapland would be manifested in the quick spread of the Lovozero Ware at the beginning of the Bronze Age (1900 B.C.) (e.g. 2000: 26-27). Recently, though, Carpelan (2003: 86-87) has slightly modified this scenario: he now proposes that along with the Lovozero Ware small Proto-Saami-speaking communities moved north and settled among the original inhabitants of the area, but that the "final" Lappicisation would only have occurred when Kjelmøy Ware spread over Lapland at the beginning of the Iron Age (650 B.C.). Carpelan also suggests that a divergent development of the 'northwestern' and 'southeastern segments' of the Proto-Saami area (i.e., Lapland vs. eastern Finland and Karelia) started at the beginning of the Bronze Age, 
because the archaeological records from these two regions differ during this period.

From a linguistic perspective this scenario still involves certain problems. One must note that it is hardly valid to speak of 'Saami' on time levels such as the beginning of the Bronze Age; as has been seen above, many of the linguistic innovations characteristic of Proto-Saami seem to date no further back than the early Iron Age, and at the turn of the Stone and Bronze Ages one could at best speak of a Pre-Saami dialect still closely resembling Proto-Uralic. For the same reason there are no grounds for postulating internal divergence within Saami in the early Bronze Age, as the language branch itself hardly even existed at such an early date. Moreover, the linguistic material available does not support an idea of distinct 'northwestern' and 'southeastern' branches of Saami: the Saami substrate toponyms in southern Finland demonstrate that the source languages had undergone the same set of Proto-Saami sound changes as their surviving sister languages in the north (Aikio in press b; Saarikivi 2004b). True, Carpelan (2004) has referred to Mikko Korhonen (1979) who proposed that the extinct Saami languages of southern Finland were descendants of a distinct 'southern Proto-Saami' language, but the rather cursory arguments Korhonen presented for his hypothesis have been refuted by Sammallahti (1984: 147-148).

In spite of these critical remarks Carpelan's hypothesis concerning the connection between the spread of Kjelmøy Ware and the Saami expansion remains chronologically quite reasonable; the beginning of the Iron Age is indeed the earliest possible date for the expansion of Proto-Saami to have taken place. It might be fruitful to conduct further linguistic and archaeological studies on the basis of this hypothesis in order to see whether additional evidence can be uncovered. In addition, it can be proposed that future research should concentrate more on a search for possible causes of prehistoric linguistic expansions; a search for mere correlations between linguistic and archaeological waves of influence involves a risk of circular argumentation, and in any case such correlations can in themselves reveal little concerning the reasons behind prehistoric language replacements. Even though the rough outlines of the development of the Saami languages in terms of space and time seem clear at present, we still know essentially nothing of the causal factors behind the Saami expansion which has completely transformed the ethnic map of Fennoscandia.

\section{Notes}

${ }^{1}$ I wish to thank Jorma Koivulehto, Pekka Sammallahti and an anonymous referee for valuable comments on an earlier manuscript.

${ }^{2}$ Actually even long before Koivulehto's studies it had been recognised that there are words of Germanic origin in Saami which show the diphthong $u$ o in place of Germanic * $a$ (see e.g. Wiklund 1896: 141-145). But as this did not accord with the general assumption of the late onset of the Germanic contacts, such words were either anachronistically regarded as Scandinavian loans 
or it was maintained that they had been mediated by Finnic. There were even attempts to explain these words away by resorting to irregular sound changes (Sköld 1961: 95-97).

${ }^{3}$ The Proto-Saami reconstructions applied in this paper are phonological, and originally allophonic phenomena such as consonant gradation are not indicated (cf. the phonetically detailed reconstruction applied by Sammallahti 1998). The same principle is applied in the Germanic reconstructions, and hence oppositions such as $d: d$ etc. are not indicated. Proto-Saami $* \ddot{e}$ stands for a mid central unrounded vowel.

${ }^{4}$ Note that the homonymous PS stem *luoskë- (> SaaN luoskkas 'ramschackle (of wooden things)', luoskkagit 'to become ramsackle') mentioned by Koivulehto in this connection may be of different origin: cf. Finn. lohjeta (lohkea-) 'to cleave, split, rift (intr.)', Mari luškodo 'loose, slack, soft' < *loški-.

${ }^{5}$ Admittedly, a narrow distribution does not prove the late origin of a word, but this criterion is still suggestive.

${ }^{6}$ The term 'Northwestern Saami' should not be understood as a taxonomic category, i.e. a subbranch of Proto-Saami, but merely a hypothetical dialect group within Proto-Saami that shared the phonological features discussed.

${ }^{7}$ Incidentally, the inspiration for this etymology was provided by a comparison of Finnish pullea and English full by Korpinen (1995: 115), a pseudoscientific work containing thousands of extravagant word comparisons between Finnish, Germanic, Japanese, Egyptian, etc.

${ }^{8}$ As a side note, the word borsi provides a plausible etymological explanation for the North Saami river name Bis'sojohka ('gun-river') in the municipality of Porsanger. The original Saami name was probably *Borsejohka, which was borrowed into Norwegian and then folketymologically reinterpreted as Børselv 'gun-river'; the present Saami name is then a calque of the Norwegian name. The most notable feature of the river in question is that it rushes in torrents through a deep canyon that is several kilometres long, which perfectly accords with the meaning of SaaN borsi. In contrast, a word meaning 'gun' does not provide a semantically and typologically natural basis for this river name.

${ }^{9}$ Note that SSA needlessly considers the loan origin of Finn. tuppi uncertain, and presents the unlikely suggestion that the word might instead be of "autochthonous descriptive origin".

${ }^{10}$ Note that the Germanic origin of kalea 'cool; hard' is rejected without argumentation by SSA (s.v.), which instead puts forward the suggestion that the word could be of onomatopoeic origin and connected with kalista 'to clatter, rattle'. For some reason, though, the similar word kolea 'cool, chilly; rough' is not compared to kolista 'to clatter, rattle' in the dictionary.

${ }^{11}$ Sammallahti writes the word as ruošši, but according to his dictionary orthography the correct form would be ruošš $i$, as the word has a Quantity III geminate; the GenSg is ruošši instead of *ruoši.

${ }^{12}$ The verb häätää seems to have a previously unnoticed cognate in Saami: SaaS sietedh 'to drive (a reindeer herd)' < PS *seatē- <*š̈̈tä-.

${ }^{13}$ In spite of this evidence several scholars, especially in the field of archaeology, have chosen to reject an earlier presence of Saami in southern Finland. However, this view seems to derive from ignorance of the historical and linguistic evidence as well as from a confusion of ethnic and archaeological concepts. As an example one can mention Huurre (1979: 151-154; 1995: 349) who speculates that the Bronze Age 'Sär-2 Ware' in Lapland is connected with the Saami. Because the same type of ware is not found in southern Finland he concludes that the historical 'Lapps' in this area cannot have been ethnically Saami even if they had spoken a Saami language. To this one 
must say that it is simply absurd to redefine historically known ethnic groups on the basis of Bronze Age distributions of types of ceramics.

${ }^{14}$ Some examples can be given. Larsson $(1988 ; 1990)$ suggests that the Uralic homeland could originally have stretched from the Baltic Sea to the Ural Mountains, and maintains that the 3500kilometre wide territory occupied by the Cree in the Canadian forest zone provides a parallel for this hypothesis. In reality, though, the Cree became incorporated in the fur trade run by Europeans, and their wide territory is the result of a rapid westward expansion triggered by the adoption of firearms and advanced trapping technology (Ray 1996: 278-280); hence this alleged parallel only serves as an argument against the idea of wide homelands. On the other hand, Niskanen (2003) maintains that the wide spread of Athabaskan languages supports the hypothesis of a huge but linguistically uniform Uralic homeland. This argument is no more convincing than Larsson's, because the Athabaskan territory has not remained linguistically uniform at all: Proto-Athabaskan has diverged into as many as 38 distinct languages each of which is spoken in a narrow area. In general it can be said that it is futile to search for parallels for huge homelands in North America which prior to its colonisation was occupied by nearly 300 distinct languages forming at least 57 families and isolates (Mithun 2001: 326-586).

${ }^{15}$ The reconstruction *jëccë given for SaaSk jõcc in Aikio (2004: 15) must be corrected to *jëcë; the word has a voiced geminate affricate in the weak grade (cf. GenSg / NomPl jõozzz), which demonstrates that $-c c$ - reflects an original single affricate in this word.

${ }^{16}$ Recently Janhunen (2005: 85), who also argues for a late Saami expansion to Lapland, has proposed that the expansion took place due to the push factor caused by the spread of Finnic. However, this explanation seems to be chronologically inconsistent. The loanwords and placenames of Scandinavian origin in Saami reveal that Proto-Saami had dialectally disentegrated and spread over most of the present Saami area by approximately 500 A.D. (Aikio 2004: 26), but at this time the Finno-Karelian agricultural expansion was still in its initial stage. In Finland it had not progressed beyond Finland Proper and the central parts of Tavastia (Salo 2000), and it is difficult to see how pressure in such a limited area could have caused Saami to expand a thousand kilometres north and even further into the Scandinavian Peninsula.

${ }^{17}$ The observed archaeological 'continuity' in Lapland is not necessarily a totally irrelevant phenomenon in respect to linguistic history, though. While a direct equation of continuity of (material) culture with the genetic descent of language is a category mistake, it can be proposed that there is a level in language which better correlates with archaeological continuity, namely substrate. As noted above, the Palaeo-European substrate lexicon in the Saami languages contains hundreds of lexical items, and the sheer extent of this stratum suggests that also the cultural impact of these lost ethnic groups has been massive. For instance, there is many times more substrate vocabulary in Saami connected with hunting and fishing than there are inherited Uralic words in the same semantic field. Thus, one in fact expects to find evidence of cultural continuity in Lapland regardless of the absence of linguistic and ethnic continuity. 


\section{Abbreviations}

NwGerm $=$ Northwest-Germanic

$\mathrm{NwS}=$ Northwest-Saami (defined in section 2)

$\mathrm{PF}=$ Proto-Finnic

PGerm $=$ Proto-Germanic

PreF $=$ Pre-Finnic

PreS $=$ Pre-Saami

$\mathrm{PS}=$ Proto-Saami

PScand $=$ Proto-Scandinavian

SaaI $=$ Inari Saami

SaaK $=$ Kildin Saami

$\mathrm{SaaL}=$ Lule Saami

SaaN $=$ North Saami

$\mathrm{SaaP}=$ Pite Saami

$\mathrm{SaaS}=$ South Saami

SaaSk $=$ Skolt Saami

$\mathrm{SaaT}=$ Ter Saami

$\mathrm{SaaU}=\mathrm{Ume}$ Saami

\section{References}

\section{Archives}

LAFD = The Lexical Archive of Finnish Dialects. The Research Institute for the Languages of Finland, Helsinki.

\section{Literature}

$\mathrm{AEWb}=\mathrm{De}$ Vries, Jan 1962: Altnordisches etymologisches Wörterbuch. Zweite, verbesserte Auflage. Leiden: E. J. Brill.

Aikio, Ante 2004: An essay on substrate studies and the origin of Saami. - Irma Hyvärinen, Petri Kallio \& Jarmo Korhonen (eds.), Etymologie, Entlehnungen und Entwicklungen: Festschrift für Jorma Koivulehto zum 70. Geburtstag. Mémoires de la Société Néophilologique de Helsinki 63. Helsinki: Société Néophilologique. 5-34.

Aikio, Ante (in press a): Etymological nativization of loanwords: a case study of Saami and Finnish. - Diane Nelson, Ida Toivonen \& Mikael Vinka (eds.), Saami linguistics. John Benjamins.

Aikio, Ante (in press b): The study of Saami substrate toponyms in Finland. - Ritva Liisa Pitkänen \& Janne Saarikivi (eds.), The borrowing of place names in the Finno-Ugric languages. Onomastica Uralica 4. Debrecen - Helsinki.

Ariste, Paul 1971: Die ältesten Substrate in den ostseefinnischen Sprachen. - Sovetskoe finno-ugrovedenie 7: 251-258. 
ASD = Bosworth, Joseph 1882-1887: An Anglo-Saxon dictionary. Edited and enlarged by T. Northcote Toller. Oxford: Oxford University Press.

Bergsland, Knut \& Mattsson Magga, Lajla 1993: Aarjelsaemien-daaroen baakoegaerja - Sydsamisk-norsk ordbok. [Lakselv:] Iđut.

Carpelan, Christian 2000: Essay on archaeology and languages in the Western end of the Uralic zone. - Congressus nonus internationalis fenno-ugristarum, Pars I: Orationes plenariae \& Orationes publicae. Tartu. 7-38.

Carpelan, Christian 2003: Inarilaisten arkeologiset vaiheet. - Veli-Pekka Lehtola (ed.), Inari - Aanaar. Inarin historia jääkaudesta nykypäivään. Oulu: Inarin kunta. 2895.

Carpelan, Christian 2004: Etnicitet, identitet, ursprung? Exemplet Samerna. A plenary paper read at the 22nd Nordic Archaeology Conference, University of Oulu, 19th August 2004.

Carpelan, Christian \& Parpola, Asko 2001: Emergence, contacts and dispersal of ProtoIndo-European, Proto-Uralic and Proto-Aryan in archaeological perspective. Christian Carpelan, Asko Parpola \& Petteri Koskikallio (eds.), Early contacts between Uralic and Indo-European: Linguistic and archaeological considerations. Mémoires de la Société Finno-Ougrienne 242. Helsinki: Suomalais-Ugrilainen Seura. 55-150.

CEDEL $=$ Klein, Ernest 1966-1967: A comprehensive etymological dictionary of the English language. Amsterdam - London - New York: Elsevier Publishing Company.

DEWOS = Steinitz, Wolfgang 1966-1991: Dialektologisches und etymologisches Wörterbuch der ostjakischen Sprache. Berlin: Akademie-Verlag.

Friis, Jens Andreas 1887: Lexicon Lapponicum. Christiania: Jacob Dybwald.

Grundström, Harald 1946-1954: Lulelapsk ordbok. Skrifter utgivna genom dialekt- och folkminnesarkivet i Uppsala. Ser. C:1. Uppsala: A.-B. Lundequistska Bokhandeln.

Halász, Ignacz 1891: Svéd-Lapp nyelv IV: Déli-Lapp szótár. Budapest: Magyar tudományos Akadémia.

Halinen, Petri 1999: Saamelaiset - arkeologinen näkökulma. - Paul Fogelberg (ed.), Pohjan poluilla. Suomalaisten juuret nykytutkimuksen mukaan. Bidrag till kännedom av Finlands natur och folk 153. Helsinki: Societas Scientiarum Fennica. 121-130.

Hansen, Lars Ivar \& Olsen, Bjørnar 2004: Samenes historie fram til 1750. Oslo: Cappelen Akademisk Forlag.

Huurre, Matti 1979: 9000 vuotta Suomen esihistoriaa. Helsinki: Otava.

Huurre, Matti 1995: Kivikauden Suomi. Helsinki: Otava.

IED = An Icelandic-English dictionary. Initiated by Richard Gleasby. Subsequently revised, enlarged and compiled by Gudbrand Vigfusson. Second edition. 1957. Oxford: The Clarendon Press.

ÍO = Magnússon, Ásgeir Blöndal 1989: Íslensk orðsifjabók. Reykjavík: Orðabók Háskólans.

Itkonen, Erkki 1986-1991: Inarilappisches Wörterbuch. Lexica Societatis FennoUgricae XX. Helsinki: Suomalais-Ugrilainen Seura.

Itkonen, T. I. 1947: Lapparnas förekomst i Finland. - Ymer 1947: 43-57. 
Itkonen, T. I. 1958: Koltan- ja kuolanlapin sanakirja. Lexica Societatis Fenno-Ugricae XV. Helsinki: Suomalais-Ugrilainen Seura.

Janhunen, Juha 1977: Samojedischer Wortschatz: Gemeinsamojedische Etymologien. Castrenianumin toimitteita 17. Helsinki.

Janhunen, Juha 2005: När kom finnarna till Finland? - Sphinx 2004-2005: 77-91.

Kallio, Petri 2006: Suomen kantakielten absoluuttista kronologiaa. - Virittäjä 110: 225.

Kluge $=$ Kluge, Friedrich 1995: Etymologisches Wörterbuch der Deutschen Sprache. Bearbeitet von Elmar Seebold. 23., erweiterte Auflage. Berlin - New York: Walter de Gruyter.

Koivulehto, Jorma 1976: Vanhimmista germaanisista lainakosketuksista ja niiden ikäämisestä. - Virittäjä 80: 33-47, 247-290.

Koivulehto, Jorma 1981: Zur Datierung der germanisch-finnischen Lehnbeziehungen. Congressus Quintus Internationalis Fenno-Ugristarum Turku 20.-27.VIII.1980. 7: Dissertationes sectionum: Lexicologia et onomastica, alia linguistica et litteraria. Turku. 73-78.

Koivulehto, Jorma 1986: Die Sieverssche Regel im Lichte der germanisch-finnischen Lehnbeziehungen. - Bela Brogyani \& Thomas Krümmelbein (eds.), Germanic dialects: Linguistic and philological investigations. Current Issues in Linguistic Theory 38. Amsterdam: Benjamin. 249-294. (Reprinted in Koivulehto 1999a.)

Koivulehto, Jorma 1988: Lapin ja itämerensuomen suhteesta: ieur. -Tr-yhtymän korvautuminen lainoissa. - Virittäjä 92: 48-51. (German summary reprinted in Koivulehto 1999 a.)

Koivulehto, Jorma 1992: Direkte Kontakte des Lappischen mit dem Baltischen. - Pál Deréky, Timothy Riese, Marianne Sz. Bakró-Nagy \& Péter Hajdú (eds.), Festschrift für Károly Rédei zum 60. Geburtstag - Emlékkönyv Rédei Károly 60. születésnapjára. Studia Uralica 6. Wien - Budapest: MTA Nyelvtudományi Intézet. 299-304.

Koivulehto, Jorma 1996: Tykkä-sanan ja tykkylumen alkuperä. - Hiidenkivi 6/1996: 36.

Koivulehto, Jorma 1999a: Verba mutuata. Quae vestigia antiquissimi cum Germanis aliisque Indo-Europaeis contactus in linguis Fennicis reliquerint. Edidit Klaas $\mathrm{Ph}$. Ruppel. Mémoires de la Société Finno-Ougrienne 237. Helsinki: FinnischUgrische Gesellschaft.

Koivulehto, Jorma 1999b: [Review of LÄGLOS, Bd. II.] - Kratylos 44: 119-122.

Koivulehto, Jorma 2002: Contact with non-Germanic languages II: relations to the east. - Oskar Bandle, Kurt Braunmüller, Ernst Håkan Jahr, Allan Kraker, Hans-Peter Naumann \& Ulf Teleman (eds.), The Nordic languages. An international handbook of the history of the North Germanic languages. Vol. 1. Berlin - New York: Walter de Gruyter. 583-594.

Koponen, Eino 1996: Lappische Lehnwörter im Finnischen und Karelischen. - Lars Gunnar Larsson (ed.), Lapponica et Uralica. 100 Jahre finnisch-ugrischer Unterricht an der Universität Uppsala. Studia Uralica Uppsaliensia 26. Uppsala: Finsk-ugriska institutionen. 83-98.

Korhonen, Mikko 1979: Lapin kielen varhaisvaiheista. - Suomalainen tiedeakatemia. Vuosikirja 1977: 129-140. 
Korhonen, Olavi 1979a: Bákkogir'je julevusámes dárrui, dáros julevusábmái lulesamisk-svensk, svensk-lulesamisk ordbok. Uppsala: Almqvist \& Wiksell.

Korhonen, Olavi 1979b: Lappische Lehnwörter im ältesten Einödgebiet Finnlands. Finnisch-Ugrische Forschungen 43: 175-206.

Korpinen, Tuulikki 1995: Jänis-myytti etymologisena impulsina [sic]. Uusinta tietoa suomen kielen suhteista indoeurooppalaisiin kieliin, japaniin ja muinaisegyptiin. Heinola: published by the author.

Lagercrantz, Eliel 1939: Lappischer Wortschatz. Lexica Societatis Fenno-Ugricae VI. Helsinki: Suomalais-Ugrilainen Seura.

LÄGLOS = A. D. Kylstra, Sirkka-Liisa Hahmo, Tette Hofstra \& Osmo Nikkilä 1991-: Lexikon der älteren germanischen Lehnwörter in den ostseefinnischen Sprachen. Amsterdam - Atlanta: Rodopi B.V.

Larsson, Lars-Gunnar 1988: Zum Problem der uralischen Urheimat. - Linguistica Uralica 26: 230-238.

Larsson, Lars-Gunnar 1990: Urhemmet, stamträdet och språkkontakterna. - Ingrid Almqvist, Per-Erik Cederholm \& Jarmo Lainio (eds.), Från Pohjolas pörten till kognitiv kontakt. Vänskrift till Erling Wande den 9 maj 1990. Stockholm Studies in Finnish Language and Literature 6. Stockholm: Department of Finnish, Stockholm University. 105-116.

Mallory, J. P. 2001: Uralics and Indo-Europeans: Problems of time and space. Christian Carpelan, Asko Parpola \& Petteri Koskikallio (eds.), Early contacts between Uralic and Indo-European: Linguistic and archaeological considerations. Mémoires de la Société Finno-Ougrienne 242. Helsinki: Suomalais-Ugrilainen Seura. 345-366.

Mithun, Marianne 2001. The Languages of Native North America. Cambridge: Cambridge Univerity Press.

Mullonen, I. I. 2002. Toponimija Prisvir'ja: problemy ètnojazykovogo kontaktirovanija. Petrozavodsk: Petrozavodskij gos. un-t.

Nielsen, Konrad 1979: Lappisk (samisk) ordbok - Lapp dictionary. 2. opplag. Oslo: Instituttet for sammenlignende kulturforskning.

Nikkilä, Osmo 1981: Germaanisperäisiä 'reippaita' sanoja itämerensuomessa. Sananjalka 23: 63-82.

Niskanen, Markku 2003: Eurooppalaisten biologiset juuret. - Kaltio 5/2003.

Odner, Knut 1983: Finner og terfinner: etniske prosesser $i$ det nordlige FennoSkandinavia. Oslo Occasional Papers in Social Anthropology no. 9. Oslo: Department of Social Anthropology.

OED = The Oxford English dictionary. Second edition. Oxford: Oxford University Press. 1989.

Qvigstad, J. 1893: Nordische Lehnwörter im Lappischen. Christiania VidenskabsSelskabs Forhandlinger for 1893 No. 1. Christiania: Grøndahl \& Søn.

Qvigstad, J. 1944: De lappiske appellative stedsnavn. Instituttet for sammenlignende kulturforskning, Serie B: Skrifter, XLII. Oslo.

Ray, Arthur J. 1996: The Northern interior, 1600 to modern times. - Bruce G. Trigger \& Wilcolm E. Washburn (eds.), The Cambridge history of the native peoples of the Americas. Volume 1, Part 2. Cambridge: Cambridge University Press. 259-327. 
Saarikivi, Janne 2004a: Is there Palaeo-European substratum interference in the western branches of Uralic? - Journal de la Société Finno-Ougrienne 90: 187-214.

Saarikivi, Janne 2004b: Über das saamische Substratnamengut in Nordrußland und Finnland. - Finnisch-Ugrische Forschungen 58: 162-234.

Salmons, Joe 1992: Northwest Indo-European vocabulary and substrate phonology. Roger Pearson (ed.), Perspectives on Indo-European language, culture and religion: studies in honor of Edgar C. Polomé. Vol. 2. Journal of Indo-European Studies, Monograph Series 9: 265-279.

Salo, Unto 2000: Suomi ja Häme, Häme ja Satakunta. - Jukka Peltovirta (ed.), Hämeen käräjät I. Hämeenlinna - Harjavalta: Hämeen Heimoliitto ry - Emil Cedercreutzin säätiö. 18-231.

Sammallahti, Pekka 1984: Saamelaisten esihistoriallinen tausta kielitieteen valossa. Jarl Gallén (ed.), Suomen väestön esihistorialliset juuret. Tvärminnen symposiumi 17.-19.1.1980. Bidrag till Kännedom av Finlands Natur och Folk 131. Helsinki: Societas Scientiarum Fennica. 137-156.

Sammallahti, Pekka 1989: Sámi-suoma sátnegirji - Saamelais-suomalainen sanakirja. Ohcejohka: Jorgaleaddji Oy.

Sammallahti, Pekka 1998: The Saami languages - an introduction. Kárášjohka: Davvi girji.

Sammallahti, Pekka 1999: Saamen kielen ja saamelaisten alkuperästä. - Paul Fogelberg (ed.), Pohjan poluilla. Suomalaisten juuret nykytutkimuksen mukaan. Bidrag till kännedom av Finlands natur och folk 153. Helsinki: Societas Scientiarum Fennica. 70-90.

Sammallahti, Pekka \& Morottaja, Matti 1993: Säämi-suomâ sänikirje Inarinsaamelais-suomalainen sanakirja. Ohcejohka: Girjegiisá.

Sammallahti, Pekka \& Mosnikoff, Jouni 1988: U'cc sää'm-lää'dd sää'nnkêarjaž Pieni koltansaame-suomi sanakirja. Utsjoki: Jorgaleaddji.

Schlachter, Wolfgang 1958: Wörterbuch des Waldlappendialekts von Malå und Texte zur Ethnographie. Lexica Societatis Fenno-Ugricae XIV. Helsinki: SuomalaisUgrilainen Seura.

SEO = Hellquist, Elof 1939: Svensk etymologisk ordbok. 2. upplag. Lund: Gleerups.

SKES = Suomen kielen etymologinen sanakirja . Lexica Societatis Fenno-Ugricae XII. Helsinki: Suomalais-Ugrilainen Seura. 1955-1981.

Sköld, Tryggve 1961: Die Kriterien der urnordischen Lehnwörter im Lappischen. Skrifter utgivna av Institutionen för nordiska språk vid Uppsala universitetet 8. Uppsala: Almqvist \& Wiksell.

SSA = Itkonen, Erkki \& Ulla-Maija Kulonen (toim.) 1992-2000: Suomen sanojen alkuperä. Etymologinen sanakirja. Suomalaisen kirjallisuuden seuran toimituksia 556, Kotimaisten kielten tutkimuskeskuksen julkaisuja 62. Helsinki: Kotimaisten kielten tutkimuskeskus - Suomalaisen kirjallisuuden seura.

Thomsen, Vilhelm 1869: Den gotiske sprogklasses indflydelse på den finske. København: den Gyldendalske boghandel.

Thomsen, Vilhelm 1890: Berøringer mellem de finske og de baltiske (litauisk-lettiske) Sprog. København: Blanco Lunos.

UEW = Rédei, Károly 1988-1991: Uralisches Etymologisches Wörterbuch. Budapest: Akadémiai Kiadó. 
VA = Bjorvand, Harald \& Lindeman, Frerik Otto 2000: Våre arveord - etymologisk ordbok. Oslo: Novus Forlag - Instituttet for sammenlignende kulturforskning.

Wiklund, K. B. 1896: Entwurf einer urlappischen Lautlehre. Mémoires de la Société Finno-Ougrienne 10. Helsingfors: Société Finno-Ougrienne.

YSS = Lehtiranta, Juhani 1989: Yhteissaamelainen sanasto. Mémoires de la Société Finno-Ougrienne 200. Helsinki: Suomalais-Ugrilainen Seura.

Ante Aikio <ante.aikio@oulu.fi>

Giellagas Institute for Saami Studies

P.O. Box 1000

FI-90014 University of Oulu 